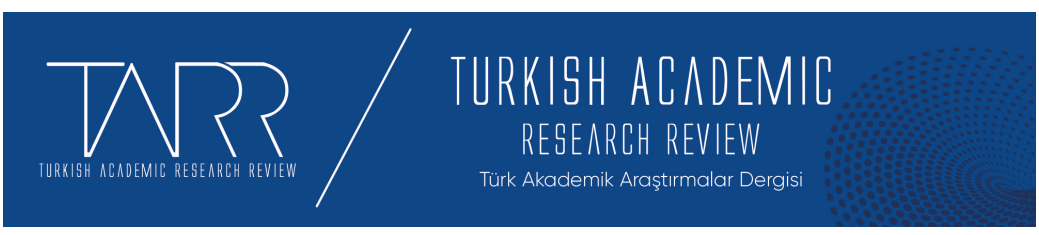

e-ISSN: 2602-2923 Yll/Year: 2021 Cilt/Volume: 6 Sayı/Issue: 3

\title{
Eleştirel Düşünme Eğiliminin Dindarlık Üzerine Etkisi: İlahiyat Fakültesi Öğrencileri Örneği
}

The Effect of Critical Thinking Tendency on Religiosity: Theology Faculty Students Example

\section{Ali YÜKSEL - Şeyma Nur KAYACAN - Ahmet ÇAKMAK - Muhammed KIZILGEÇITT}

Yüksek Lisans Öğrencisi, Atatürk Üniversitesi, İlahiyat Fakültesi, Din Psikolojisi Anabilim Dal1, aliyukse191@gmail.com, Orcid ID: 0000-0002-5099-343X

Yüksek Lisans Öğrencisi, Atatürk Üniversitesi, İlahiyat Fakültesi, Din Psikolojisi Anabilim Dal1, Seyma_1997@outlook.com, Orcid ID: 0000-0001-6059-9850

Dr. Öğr. Üyesi, Atatürk Üniversitesi, İlahiyat Fakültesi, Din Eğitimi Anabilim Dalı / Doctor, Atatürk University, Faculty of Theology, Department of Education of Religion, ahmetcakmak@atauni.edu.tr, Orcid ID: 0000-0002-4351-156X

Doç. Dr., Atatürk Üniversitesi, İlahiyat Fakültesi, Din Psikolojisi Anabilim Dalı / Associate Professor, Atatürk University, Faculty of Theology, Department of Psychology of Religion, mkizilgecit@atauni.edu.tr, Orcid ID: 0000-0002-8914-5681

\begin{tabular}{r|l} 
Makale Bilgisi & Article Information \\
Makale Türü - Article Type & Araştırma Makalesi / Research Article \\
Geliş Tarihi - Date Received & 13 Temmuz / July 2021 \\
Kabul Tarihi - Date Accepted & 16 Eylül / September 2021 \\
Yayın Tarihi - Date Published & 20 Eylül / September 2021 \\
Yayın Sezonu & Temmuz - Ağustos - Eylül \\
Pub Date Season & July - August - September
\end{tabular}

Atıf / Cite as: Yüksel, A.-Kayacan, Ş.N.-Çakmak, A.-Kızılgeçit, M. (2021), Eleştirel Düşünme Eğiliminin Dindarlık Üzerine Etkisi: İlahiyat Fakültesi Öğrencileri Örneği/The Effect of Critical Thinking Tendency on Religiosity: Theology Faculty Students Example. Turkish Academic Research Review, 6 (3), 1086-1132. Retrieved from https://dergipark.org.tr/tr/pub/tarr/issue/64962/970684

Intihal / Plagiarism: Bu makale, en az iki hakem tarafından incelenmiş ve intihal içermediği teyit edilmiştir. / This article has been reviewed by at least two referees and confirmed to include no plagiarism. https://dergipark.org.tr/tr/pub/tarr

Copyright (C) Published by Mehmet ŞAHIN Since 2016- Akdeniz University, Faculty of Theology, Antalya, 07058 Turkey. All rights reserved.

Turkish Academic Research Review - Türk Akademik Araştırmalar Dergisi 


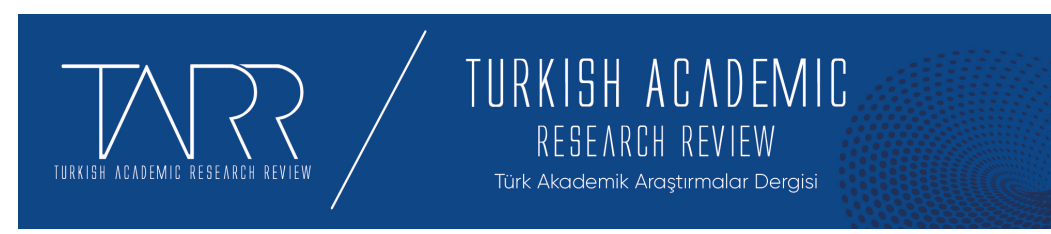

e-ISSN: 2602-2923 Yll/Year: 2021 Cilt/Volume: 6 Sayı/Issue: 3

\title{
Eleştirel Düşünme Eğiliminin Dindarlık Üzerine Etkisi: İlahiyat Fakültesi Öğrencileri Örneği
}

\author{
Ali YÜKSEL-Şeyma Nur KAYACAN-Ahmet ÇAKMAK- \\ Muhammed KIZILGEÇİT
}

Öz

Araştırma amacı üniversite öğrencilerinin eleştirel düşünme eğilimi ve motivasyonel dindarlık düzeylerinin bazı değişkenlere göre farklılaşıp farklılaşmadığını ve eleştirel düşünme eğiliminin motivasyonel dindarlık düzeyini ne derecede etkilediğini incelemektir. $\mathrm{Bu}$ doğrultuda çalışma nicel araştırma yöntemlerinden ilişkisel tarama modeline göre tasarlanmıştır. Çalışmanın veri toplama araçları olarak Semerci (2016) tarafindan geliştirilen Eleştirel Düşünme Eğilimi Ölçeği (EDE) ve Karaca (2001) tarafindan uyarlanan İçsel Dinî Motivasyon Ölçeği (IDMÖ) kullanılmıştır. Araştırmanın örneklemi Atatürk Üniversitesi İlahiyat Fakültesinde 2020-2021 akademik yılında öğrenim gören 236’s1 (\%79,7) k1z ve 60’1 $(\% 20,3)$ erkek olmak üzere toplam 296 öğrenciden oluşmaktadır. Elde edilen veriler SPSS 20.0 istatistik paket programı kullanılarak analiz edilmiştir. Bu kapsamda eldeki veri setinde bağımsız değişkenlerden iki gruplu olanlar için ilişkisiz örneklemler T Testi, üç veya daha fazla gruplu bağımsız değişkenlerde ise One Way ANOVA testi kullanılmıştır. Eleştirel düşünme eğilimi ile içsel dinî motivasyon düzeyi arasındaki ilișkiyi belirlemek amacıyla Pearson Moment Korelasyon analizi yapılmıştır. Değişkenler arasındaki ilişkinin matematiksel bağıntısını belirlemek amacıyla çoklu doğrusal regresyon analizinden faydalanılmıştır. Sosyo-demografik değişkenler olan cinsiyet, sınıf, yaşanılan ortam, algılanan aile yapısı ve aile dindarlık düzeyine göre bağımlı değişkenlerin farklılaşmasına yönelik sonuçlar sunulmuştur. Elde edilen bulgulara göre eleştirel düşünme eğilimi ile içsel dinî motivasyon düzeyi arasında istatistiksel olarak yüksek düzeyde pozitif yönde anlamlı ilişki tespit edilmiştir. Eleştirel düşünme eğiliminin üstbiliş, esneklik, sistematiklik, azim ve sabır alt boyutları ile içsel dinî motivasyon arasında istatistiksel olarak pozitif yönde anlamlı ilişki tespit edilmiştir. Eleştirel düşünme eğiliminin açık fikirlilik alt boyutu ile içsel dinî motivasyon arasında istatistiksel olarak anlamlı ilişkiye ulaşılamamıştır. Elde edilen bulgular 1şı̆̆ında eleştirel düşünme eğilimine sahip bireylerin içsel dinî motivasyon düzeylerinin yani dindarlık seviyelerinin yüksek olduğu tespit edilmiştir. Ayrıca çoklu doğrusal regresyon analizi sonuçlarına göre eleştirel düşünmenin dinî motivasyon üzerinde pozitif yönlü anlamlı bir yordayıcı olduğu, içsel dinî motivasyona ait toplam varyansın \%4'ünün eleştirel düşünme eğiliminin esneklik alt boyutu ile açıklandığı sonucuna ulaşılmıştır. Son yıllarda ülkemizde eleştirel düşünme üzerine nicel veya nitel birçok çalışma gerçekleştirilmekte ve eleştirel düşünme eğilimini etkileyen birçok değişken üzerinde durulmaktadır. Bütün araştırma verilerinin ortaya konulduğu meta analitik çalışmalar yapılması hem eleştirel düşünmenin tanımlanması hem de eleştirel düşünme becerisinin öğretilebilmesi ve geliştirilebilmesi açısından değerli olacağı düşünülmektedir.

Anahtar Kelimeler: Din Psikolojisi, İlahiyat Fakültesi Öğrencileri, Eleştirel Düşünme, Dindarlık, Nicel Araştırma

Turkish Academic Research Review - Türk Akademik Araştırmalar Dergisi 


\title{
The Effect of Critical Thinking Tendency on Religiosity: Theology Faculty Students Example
}

\begin{abstract}
The aim of the research is to examine whether university students' critical thinking disposition and their levels of motivational religiosity differ according to some variables and to what extent the critical thinking disposition affects their motivational religiosity level. In this context, the study was designed according to the relational scanning model, one of the quantitative research methods. The Critical Thinking Disposition Scale developed by Semerci (2016) and the Internal Religious Motivation Scale adapted by Karaca (2001) were used as the data collection tools of the study. The sample of the study consists of a total of 296 students, $236(79.7 \%)$ girls and $60(20.3 \%)$ boys, studying in the Faculty of Divinity at Atatürk University in the 2020-2021 academic year. The data obtained were analysed using the SPSS 20.0 statistical package program. Independent samples T-Test was used for independent variables with two groups, and One Way ANOVA test was used for independent variables with three or more groups. Pearson Moment Correlation analysis was conducted to determine the relationship between critical thinking disposition and intrinsic religious motivation. Multiple linear regression analysis was used to determine the degree of relationship between variables. It was determined that the dependent variables differ according to socio-demographic variables (gender, class, living environment, perceived family structure and family religiousness level). According to the findings, a statistically significant relationship was found between critical thinking disposition and intrinsic religious motivation. A statistically positive significant relationship was found between the metacognition, flexibility, systematicity, perseverance and patience sub-dimensions of critical thinking disposition and intrinsic religious motivation. There was no statistically significant relationship between open-mindedness sub-dimension of critical thinking disposition and intrinsic religious motivation. In the light of the findings, it was concluded that individuals with critical thinking disposition have high levels of intrinsic religious motivation, in other words, religiosity. In addition, according to the results of multiple linear regression analysis, it was concluded that critical thinking is a positive and significant predictor on religious motivation, and $4 \%$ of the total variance of intrinsic religious motivation is explained by the flexibility subdimension of critical thinking disposition. In recent years, many quantitative or qualitative studies on critical thinking have been carried out in our country and many variables that affect critical thinking disposition have been emphasized. It is thought that conducting meta-analytical studies in which all research data are presented will be valuable in terms of both defining critical thinking and teaching and developing critical thinking skills.
\end{abstract}

Keywords: Psychology of Religion, Students at Theology Faculty, Critical Thinking, Religiosity, Quantitative Research 
1088 Eleştirel Düşünme Eğiliminin Dindarlık Üzerine Etkisi: İlahiyat Fakültesi

Öğrencileri Örneği

\section{Structured Abstract}

In this century, as correct information is spoken more than information, our ways of obtaining information are becoming more and more important. One of the important skills we can acquire in order to reach correct information is critical thinking skill. Critical thinking enables people to notice the flow around them. However, the main importance of critical thinking is that it gives people the opportunity to examine, evaluate and question their own feelings and thoughts. Critical thinking is a skill that makes themselves, their beliefs, feelings, and thoughts ask "Why?".

Beliefs are not as transient phenomena as information. Information changes every day, with updates, but beliefs are relatively permanent. While knowledge is universal, beliefs are qualitatively subjective, although they are universal in their existence. At this point, belief is renewed or changed only by the questions that the believers ask themselves. Beliefs that have gone through various stages of reasoning and answered different questions constitute a solid support for people, while beliefs that are not questioned or thought about in any way become a burden on people. This relationship between belief and critical thinking may also be present between religion and critical thinking. Abuse of religion is seen as an important issue today and one of the important points in terms of preventing this abuse is to have critical thinking skills. The relationship between religiosity and critical thinking can be addressed in the Religious Psychology literature in terms of religious development processes and dimensions of religiosity: cognitive dimensions, knowledge dimension and intrinsic religiosity.

\section{Objectives of the study}

The main purpose of the study is to determine the relationship between critical thinking dispositions and religiosity levels in students of the Faculty of Theology/Divinity using the motivational religiosity scale and the critical thinking disposition scale. In this context, the contribution of critical thinking disposition to the prediction of motivational religiousness level was discussed. Also, it was tried to determine whether there is a significant relationship between the sub-dimensions of critical thinking disposition level in the sample group and motivational religiosity. In addition, the differences in dependent variables according to socio-demographic variables were examined.

In the literature, there are studies which determined and compared the critical thinking dispositions of the students of the Faculty of Theology and the Department of Religious Education. There is also research that directly deals with the relationship between religiosity and critical thinking disposition in Turkey. However, the study addresses the point that religiosity predicts critical thinking disposition in terms of seeking an answer to the question of what effect religion has on the development of individuals' critical thoughts. This present study will focus on whether critical thinking disposition predicts religiosity using a different religiosity scale.

\section{Method}

The study was designed as a quantitative research aiming to reveal the effect of critical thinking levels of students studying at Atatürk University Faculty of Theology on their religiosity and employed the relational scanning model.

The universe of the study consists of students studying at Atatürk University Faculty of Theology in the 2020-2021 academic year. The sample of the study was composed of 296 people. Simple random sampling method was used in sample selection. As for the gender distribution of the sample, the percentage of male students is $20.3 \%(n=60)$, and female students' is $79.7 \%(n=236)$. 
In the study, the questionnaire form consisting of the Critical Thinking Disposition Scale and the Internal Religious Motivation Scale was used as a measurement tool. In the first part of the questionnaire, there are questions about the personal characteristics of the participants (gender, class, place of residence where they spent most of their life, perceived socio-economic status, perceived family structure, perceived level of family piety).

\section{Findings}

The findings regarding socio-demographic characteristics are as follows. Perceived socio-economic levels of the participants are 5.8\% (n: 17) low, 7.7\% (n: 23 ) below average, $61.8 \%$ (n: 183 ) on average, $23.3 \%$ (n: 69) above average, and 1.4\% (n: 4) high. Participants' perceived levels of religiosity to their families are $1.7 \%$ low (n: 5), $2.4 \%$ below average (n: 7$), 28.7 \%$ on average (n: 85 ), $44.3 \%$ above average (n: 131), and $22.9 \%$ high (n: 68). In terms of perceived family structure, the sample group is $16.5 \%$ authoritarian (n: 49$), 8.1 \%$ democratic (n: 24$), 4.5 \%$ indifferent (n: 13), 6.4\% overly interested (n: 19), 36.1\% protective (n: 107$), 28.4 \%$ tolerant (n: $84)$. The place where the participants lived before university was $28.4 \%$ (n: 84$)$ village, $21.3 \%$ (n: 63) town, $16.5 \%$ (n: 49) city, and 33.8\% (n: 100) metropolitan.

The findings about the differentiation between socio-demographic characteristics and critical thinking disposition indicates that there is no significant difference according to gender in the sub-dimensions of critical thinking disposition in the sample of theology faculty students $(\mathrm{p}>.05)$. In this sample group, it was also found that there is no significant difference in intrinsic religious motivation by gender $(p>.05)$. In the analysis conducted to reveal whether the sub-dimensions of critical thinking disposition differ according to the living environment, it was determined that there was no significant difference in the open-mindedness subdimension $\left(\mathrm{F}_{3 / 292}=1.595, \mathrm{p}>.05\right)$. It was determined that there was a significant difference in other sub-dimensions. It was determined that those living in metropolitan cities had higher average scores in sub-dimensions of metacognition, flexibility, systematicity, perseverance and patience compared to those living in the village. In addition, it was determined that those living in metropolitan cities had higher average scores in metacognition sub-dimension than those living in a town $(p<.05)$. In the analysis study conducted to reveal the differentiation of subdimensions of critical thinking disposition according to the socio-economic levels of the sample, no significant differentiation was found in the open-mindedness subdimension $(\mathrm{p}>.05)$. In the One Way ANOVA analysis, no significant differentiation was detected in terms of sub-dimensions of critical thinking disposition, metacognition, flexibility, perseverance and patience, according to the perceived family structure $(\mathrm{p}>.05)$. In the systematic and open-minded sub-dimensions, a significant difference was determined between students who described their families as authoritarian and those who described their families as protective $(p<.05)$. According to the findings, in the metacognitive dimension, it was determined that the average scores of those who had a high level of religiousness in their families were higher than those with a high level of average and lower, those who were above the average had higher average scores than those who were lower than the average, and those who were lower had higher scores than those who were lower than the average.

According to the results of the analysis conducted to reveal the relationship between critical thinking disposition and intrinsic religious motivation, a positive and significant relationship was found between the sub-dimensions of metacognition, flexibility, systematicity, perseverance and patience and the level of intrinsic religious motivation.

Turkish Academic Research Review - Türk Akademik Araştırmalar Dergisi 
1090 Eleştirel Düşünme Eğiliminin Dindarlık Üzerine Etkisi: İlahiyat Fakültesi Öğrencileri Örneği

According to the analysis results $(\mathrm{R}=.041, \mathrm{R} 2=.038, \mathrm{p}<.05)$ performed by including the sub-dimensions of critical thinking disposition as a predictor in the regression model predicting intrinsic religious motivation, the flexibility subdimension is a positive and significant predictor on religiosity. It was determined that it explains about $4 \%$ of the total variance of religious motivation. Accordingly, the higher the flexibility level of the individual, the higher the level of intrinsic religious motivation.

\section{Discussion and conclusion}

Flexibility dimension of critical thinking disposition refers to trying to reach all the necessary information, going into the details while comparing information, listening to and understanding different ideas, offering different solutions and applying what has been learned to different areas. In this context, flexibility can be expressed as the ability to be open to different information / ideas in the process of collecting information and to use different solutions in different areas during the application of information. However, it can be stated that the flexibility dimension expresses similar meanings with the open-mindedness sub-dimension in different critical thinking scales. Mental flexibility is one of the important factors that affect critical thinking positively, and it is the absence of prejudice and dependence on a particular group or idea. Flexibility is evaluating assumptions and reaching a consistent result. According to the results of the research, it can be assumed that the flexibility dimension predicts the level of religiosity in a meaningful way, enabling students to evaluate different religious knowledge / views and reach consistent results.

It was determined that the mean intrinsic religious motivation of the sample $(\overline{\mathrm{X}}=4.43)$ and the mean of critical thinking disposition $(\overline{\mathrm{X}}=4.01)$ was high. It can be concluded that the very high level of religiosity is because the sample consists of students of the Faculty of Theology. However, it is noteworthy that the sample's critical thinking average scores were also high in the study. In the study conducted by Duran (2020) who used the same scale, it was determined that the students of the Faculty of Theology had the lowest level of critical thinking compared to the students of the other faculties (Medicine, Engineering and Architecture, Social and Humanities Sciences). When the literature was examined, there were results showing that the critical thinking disposition is high or low in the studies conducted with undergraduate students using different scales. Despite studying at the same faculty, critical thinking levels may differ in samples composed of different universities.

\section{Giriş}

Doğru bilginin bilgiden daha çok konuşulduğu bu çağda bilgi elde etme yollarımız git gide önem kazanmaktadır. Doğru bilgiye ulaşabilmek için kazanabileceğimiz önemli becerilerden birisi de eleştirel düşünme becerisidir. Eleştirel düşünme, insanın çevresinde gerçekleşen akışı fark etmesini sağlamaktadır. Ancak eleştirel düşünmenin asıl önemi, insana kendi duygu ve düşüncelerini inceleme, değerlendirme, sorgulama firsatı vermesidir (Ramazan, 2020: 130). Eleştirel düşünme, insanın kendine yolculuğunda inançlarına, duygularına, düşüncelerine "Neden?" sorusunu sorduran beceridir. İnançlar bilgiler kadar geçici olgular değildir. Her gün bilgiler güncellenerek değişmektedir ancak inançlar nispeten kalıcıdır. Bilgiler evrensel nitelik taşırken inançlar var oluşlarıyla evrensel olsalar da 
niteliksel olarak özneldir. İşte bu noktada inanç sadece inanç sahibinin kendine sorduğu sorularla yenilenmekte ya da değişmektedir. Çeşitli akıl yürütme aşamalarından geçmiş, farklı sorulara cevap vermiş olan inançlar insana sağlam bir dayanak oluştururken hiçbir şekilde sorgulanmayan, üzerinde düşünülmeyen inançlar insana yük olmaktadır. İnanç ve eleştirel düşünme arasındaki bu ilişki din ve eleştirel düşünme için de geçerli olabilmektedir. Din istismarı günümüzde önemli bir konu olarak görülmektedir ve bu istismarın önlenmesi açısından önemli noktalardan birisi de eleştirel düşünme becerisine sahip olmaktır.

"Din afyondur." diyen Marx’a, Şeriati (2019: 31-32), "Hangi din?" sorusunu yöneltmiştir. $\mathrm{Bu}$ soru eleştirel düşünce açısından önemlidir. Şeriati, "Evet, afyondur." diyebilirdi. "Hayır, afyon değildir." de diyebilirdi. Ama o duyduğunu kabul ya da reddetmek yerine sorgulamayı seçmiştir. Bu sorgulamada eleştirel düşünmenin varlığı hissedilmektedir. Şeriati’yi takip etmek gerekirse Marx'a "Hangi dindar için din afyondur?" sorusu da sorulabilir. Bu sorunun cevabı da tıpkı soru gibi eleştirel düşünme ile yakından ilgili olması beklenmektedir. Neye, niçin, nasıl inandığını bilen insan için cevap başka, bu soruları kendine hiç sormayan insan içinse cevap bambaşkadır. Bu cevapları çeşitlendiren temel özne eleştirel düşünme ya da eleştirel düşünememedir.

Eleştirel düşünme ile ilgili yapılan pek çok çalışma bulunmaktadır. Bu çalışmaların genel olarak eğitim (Özdemir, 2005; Güven ve Kürüm, 2007; Zayif, 2008; Şenlik, Baykan ve Aycan, 2011; Coşkun, 2013; Çekin, 2013; Kuvaç ve Koç, 2014; Açışl1, 2015; Can ve Kaymakçı, 2015; Ocak, Eymir ve Ocak, 2016; Şen, 2016; Erdoğan, 2015; Duran, 2019) alanında yoğunlaştığı söylenebilmektedir. Yapılan çalışmalar ele alındığında bazı çalışmalarda eleştirel düşünmenin sosyo-demografik özelliklerle beraber analiz edildiği (Özdemir, 2005; Tümkaya ve Aybek, 2008; Çakmak, 2018), bazı çalışmalarda öğretmenlerin eleştirel düşünme eğilimlerinin araştırıldığı (Zayif, 2008; Şenlik, Baykan ve Aycan, 2011; Coşkun, 2013; Can ve Kaymakçı, 2015; Erdoğan, 2015; Polat ve Kontaş, 2018; Demirtaş, 2019; Duran, 2019), bazı çalışmalarda ise eleştirel düşünce ile empati kurma becerileri, narsist kişilik özellikleri, yazma kaygıları gibi değişkenler arasındaki ilişsinin incelendiği (Şen, 2016; Demiralp, 2017; Hakkoymaz, 2017; Avaroğulları ve Şaman, 2020) görülmektedir. Din Kültürü ve Ahlak Bilgisi öğretmenleri üzerinde yapılan çeşitli çalışmalar (Coşkun, 2013; Çekin, 2013; Erdoğan, 2015) bulunmakla beraber eleştirel düşünme ve dindarlık üzerine sadece bir çalışmanın yapıldığı görülmektedir. M. E. Duran (2020), eleştirel düşünme ve dindarlık arasındaki

Turkish Academic Research Review - Türk Akademik Araştırmalar Dergisi https://dergipark.org.tr/tr/pub/tarr 
1092 Eleştirel Düşünme Eğiliminin Dindarlık Üzerine Etkisi: İlahiyat Fakültesi Öğrencileri Örneği

ilişkiyi incelediği çalışmasında eleştirel düşünme ve dindarlık arasında negatif yönlü anlamlı bir ilişki bulmuştur. Dindarlık ve eleştirel düşünme arasındaki ilişkinin farklı örneklemler ve farklı ölçekler ile çeşitlenebileceği düşünülmektedir. Bu sebeple alanda eleştirel düşünme ve dindarlık ilişkisinin çeşitli çalışmalarla ortaya konulması gerekmektedir. İlgili gerekliliğe binaen araştırmanın yapılmasına karar verilmiştir. Araştırmanın temel amacı eleştirel düşünme ve motivasyonel iç güdümlü dindarlık arasındaki ilişkiyi tespit etmektir.

\subsection{Eleştirel Düşünme}

Bilgi çağı denilen 21. yy. kavramlarından birisi olan eleştirel düşünme özellikle bilginin işlenmesi ve üretilmesi açısından oldukça kıymetli gözükmektedir. Güncel Türkçe Sözlükleri, eleştiriyi: "bir insanl, bir eseri, bir konuyu doğru ve yanlı̧ yanlarını bulup göstermek amacıyla inceleme işi, tenkit”; düşünmeyi ise: "duyum ve izlenimlerden, tasarımlardan ayrı olarak aklın bağımsız ve kendine özgü durumu”" (Türk Dil Kurumu [TDK], 2020) olarak tanımlamıştır. Bu tanımlardan hareketle eleştirel düşünme, aklın herhangi bir olgunun doğru ve yanlış yönlerini ortaya çıkarma faaliyeti olarak tanımlanabilir.

Eleştirel düşünmenin terim olarak felsefe ve psikoloji alanında pek çok tanımı bulunmaktadır. İki farklı disiplinde, eleştirel düşünme üzerine kurgulanan paradigma farklı olduğu için tanımlar da çeşitlenmektedir (Gibson, 1995). Felsefe alanında eleştirel düşünme: iyi düşünme, gerçekçi düşünme ve tarafsız düşünme becerisine sahip olabilme temelinde ele alınmıştır (Akarsu, 1975). Psikoloji alanında ise eleştirel düşünme; öğrenme, kompleks olguların öğrenilmesinde ortaya çıkan bireysel farklılıklar ve problem çözme becerisi üzerine inşa edilmiştir (Cüceloğlu, 2000).

Mckee (1988)'ye göre eleştirel düşünme, “Sorgulamanın ve usa vurmanın dirik bir süreci, bilginin edilgen birikimine karşın etkin bir biçimde bilgiyi irdelemek ve tanimlarl, eylemleri ve inançları sorgulamak ve yapılabilmiş olan ile henüz yapılabilecek olanı düşünmektir." (aktaran Şahinel, 2007: 4). Mckee eleştirel düşünmede iki temel süreçten bahsetmektedir. Birincisi bilginin insanla karşılaşması sonucunda öznelleşmesi, ikincisi ise bu sürecin dayanması gereken sorgulama becerisinin aktifleşmesidir. Sorgulama kavramı bu tanımda bel kemiği mahiyetindedir. Chaffee ise eleştirel düşünmeyi: "Kendi düşüncemizi ve başkalarının düşüncelerini daha iyi anlayabilmek ve düşüncelerimizi anlayabilme becerilerimizi geliş̧tirmek için gerçekleştirilen aktif ve fonksiyonel bir süreç” olarak tanımlamaktadır (aktaran Kökdemir, 2001: 3). Chaffee bu tanımıyla kendi 
düşüncelerimizi anlamaya odaklanmaktadır. Aslında bir fark ediş süreci olarak eleştirel düşünmeyi ele aldığı söylenebilir. Descartes'ın meşhur mottosu "Düşünüyorum. O halde varım." üzerine yeni bir kelime ekleyerek eleștirel düşünmeyi oluşturabilmekteyiz. "Düşündüğümü düşünüyorum. $O$ halde eleştirel düşünüyorum." İnsanın düşündüğünün farkına varması ilk adım olarak görülmekle beraber devamında da insandan bu fark edişin gerekliliklerini yerine getirmesi beklenmektedir. Carrol Tama (1989) ise eleştirel düşünmeyi, "Neye inanacağına veya ne yapacağına karar vermeye odaklanan derin ve mantıkl düşünme" olarak tanımlamaktadır. İnsanların neye inanacağını seçmesi, sorgulaması, bunun üzerinde düşünmesi de eleştirel düşünce faaliyeti olarak değerlendirilmektedir.

Gündoğdu, eleştirel düşünme ile Dewey (1910: 6)'in derinlemesine düşünme kavramını eşleştirerek bu iki kavramı birbirine yakınlaştırmaktadır. Derinlemesine düşünme; "Bir inancin veya bilginin bu inanct ya da bilgiyi destekleyen kanitlar ve ortaya koyduğu sonuçlar ışığında aktif, dikkatli ve sürekli bir gözden geçirmeye, değerlendirmeye tabi tutulduğ bir düşünmedir.” (aktaran Gündoğdu, 2009). Dewey'in üst düzey bir düşünme olarak tanımladığı derinlemesine düşünmede sistematiklik, mantıksallık ve kanıta dayanma temaları bulunmaktadır (Gündoğdu, 2009). Araştırmamızda kullandığımız Eleştirel Düşünme Eğilimi ölçeğinin, "Herhangi bir konuda düşündü̆̈̈̈m zaman bir kalıba bağlı kaldiğımı fark edersem bunu aşmaya çalışırım." ş̧eklindeki 7. maddesi ve "Fikirlerin ve düşüncelerin güvenilir olup olmadı̆̆ını kontrol ederim." ş̧eklindeki 15. maddesi inançların delillerle desteklenebilirliğini ölçmektedir.

Paul ve Elder (2008)'in "kişinin düsünce sistemindeki yapıları usta bir şsekilde yöneterek ve bu yaptlara entelektüel standartlar getirerek düşünme yönteminin kalitesini artırdığı bir süreç” olarak değerlendirdikleri eleştirel düşünme özellikle yönetme kavramıyla diğer tanımlardan ayrılmaktadır. İnsanda potansiyel olarak var olan düşünce becerisini bilinçli bir şekilde kullanarak ve geliştirerek -burada süreç yönetimi önemlidir- eleştirel düşüncenin oluştuğundan bahsedilebilmektedir.

Cüceloğlu (2000), eleştirel düşünceyi "Kendi düşünce süreçlerimizin bilincinde olarak, başkalarının düşünce süreçlerini göz önünde tutarak, öğrendiklerimizi uygulayarak kendimizi ve çevremizde yer alan olayları anlayabilmeyi amaç edinen aktif ve organize zihinsel süreç." olarak tanımlamaktadır. Kendi içerisinde sistematize edilmiş bu tanım, bizi adım adım eleştirel düşünceye götürmektedir. İlk adım bilinç yani farkında olmaktır. Varlığın, düşüncenin farkında olmak. Sonrasında başkalarının varlığının farkında olmak. Senden bağımsız dönen bir dünyanın

Turkish Academic Research Review - Türk Akademik Araştırmalar Dergisi https://dergipark.org.tr/tr/pub/tarr 
1094 Eleştirel Düşünme Eğiliminin Dindarlık Üzerine Etkisi: İlahiyat Fakültesi Öğrencileri Örneği

farkında olmak. Farkında olmak ilk aşamadır sonucu ise anlamaktır. Kendini anlamak. Özellikle günümüzde de popüler olan kendini aramak, bulmak, tanımakta yine eleştirel düşüncenin bir ürünü olarak görülebilmektedir.

Söylemez (2016), eleştirel düşünce üzerine gerçekleştirdiği içerik analizi çalışmasında 86 tanımı inceleyerek bu tanımlardan 7 temel tema oluşturmuştur. Söylemez'in oluşturduğu temalar, tanımların kesişim noktalarını göstermektedir. Bu temalar: amaçlı ve kasıtlı eylem olma, bilgi toplama, akıl yürütme, esneklik, çıkarımda bulunma, değerlendirme ve uygulamadır. Bu temalar eleştirel düşünmenin yapı taşı olarak görülebilir.

Eleştirel düşünme ile ilgili yapılan tanımları inceledikten sonra eleştirel düşünme ve dini aynı potada birleştiren İlahiyat Bilimlerinden Din Felsefesi bağlamında konuyu ele almak araştırmamızı daha anlamlı kılacaktır. "Din felsefesi, dini inançları uyumluluk, tutarlılık ve makul oluş bakımından tahlil etme ve eleştirel surette değerlendirme girişimidir." (Peterson vd., 2017). Dini inançların uyumlu ve tutarlı olması ile inancın mantığının açığa çıkarılması geleneksel felsefe anlayışında da bulunmaktadır. Ancak makul oluş, doğrulanabilme ya da yanlışlanabilme din felsefesinde güncel olan bir yaklaşımdır. Özellikle dine eleştirel yaklaşımı benimseyen din felsefesi, dini akıl ölçütüyle incelemektedir ya da incelemeye çalışmaktadır. Akıl-iman ilişkisini geniş bir perspektifle inceleyen din felsefesi bu ilişki içerisinde üç temel başlık oluşturmuştur (Peterson vd., 2017).

a) Katı akılcılık: Bir inanç sisteminin kabul edilebilmesi için bu inanç sisteminin doğruluğunun ispatlanmış olması zorunludur. Katı akılcılıkta din ve inançla ilgili her şeyin doğrulanması gerekmektedir. Bunun mümkün olmadığı üzerine pek çok eleştiri alsa da gerçek doğru inancın akla kesinlikle uyacağı belirtilmektedir.

b) İmancılık: Dini inanç konuları akli değerlendirmelere tabi değildir. İmancılık, katı akılcılığın çelişiği olarak görülmektedir. Akılda dini ve inancı doğrulayacak bir özellik olmadığı, dinin ancak kalpte yaşanacağı görüşü hakimdir. Aklı tamamen devre dışı bırakan bu anlayış; neye inandığını, nasıl inandığını bilmeyen; inandığı sistem karşısında rüzgâr önündeki yaprak gibi savrulan insanların gerçek imana (!) ulaştığını söyleyebilmektedir.

c) Eleştirel akılcılık: Din ve inanç sistemlerinin ispatı mümkün olmamakla beraber bu sistemler eleştirilip değerlendirilmektedir. Eleştirel akılcılık imancılık ve katı akılcılık arasında orta yol olarak ifade edilebilmektedir. Ruhu gereği ispatlanamayan din ve inancı, eleştirel bir şekilde ele almanın gerekliliği üzerinde durmaktadır. 
Din felsefesinde genel olarak üç başlıkta incelenen din-akıl ilişkisine Yaran (1997) yeni bir boyut kazandırmıştır. Yaran'a göre akılcılık nasıl ki katı ve eleştirel olmak üzere ikiye ayrılıyorsa imancılık da pek tabi ikiye ayrılabilir. İmancılığın, ılımlı ve aşırı yönleri olabilir. Zaten imancılıkla aşırı yön kastedilmektedir ve 1lımlı, eleştirel yönünü ifade ettiği düşünülen eleştirel akılcılık bunu kapsayamamaktadır. Yaran'ın (1997) tahkiki (1lımlı, eleştirel) imancılık olarak isimlendirdiği dördüncü boyut isminden de anlaşılacağı gibi Gazali’ye dayanmaktadır. Araştırarak ve delillendirerek iman etmeyi kapsar. Eleştirel akılcılık ile zıt bir ilişki içerisinde değildir. Aksine biri diğerinin devamı niteliğindedir. Eleştirel akılcılık tahkiki imanın oluşumu için ilk adım ve zemindir. Tahkiki imancılık ise ancak eleştirel akılcılıktan sonra meydana gelmektedir. Eleştirel akılcılık, insanı her zaman tahkiki imana ulaştırmaz. Nitekim eleştirel akılcılığın temel normlarına uygun düşündüğü halde iman etmeyen pek çok insan vardır. Ancak tahkiki imanın başı mutlak olarak eleştirel akılcılıktır. Tahkiki imancılıkta insanın kendi imanı üzerine yoğunlaşması dinini sağlam temeller üzerine bina etmesi gerekmektedir (Yaran, 1997). Burada dikkatleri çekmek istediğimiz husus akıl-iman ilişkisinde eleştirel akılcılık ve tahkiki imancılık boyutlarının insana dinini veya inancını; tanıma, bilme ve anlama yönünden sistematik, tutarlı ve denenebilir bir paradigma sunduğudur. İşte Din Felsefesi'nin sağlamaya çalıştığı özelde de alana yeni bir boyut kazandıran Yaran’ın hedeflediği amaç dinin veya inancın eleştirel düşünceye dayalı bir şekilde oluşumunu sağlamaktır.

İslam Felsefesi’nde eleştirel düşüncenin yerine ve tarifine bakıldığında özellikle Kur'an-1 Kerim'de pek çok ifadeye rastlanmaktadır. Kur'an-1 Kerim'de, düşüncenin oluşumu için gerekli olan akıl üzerine çokça vurgu yapılmaktadır. Akıl sözcüğü isim olarak Kur'an-1 Kerim'de geçmemekle beraber fiil kalıbıyla geçmektedir. Ayrıca akıl yerine anlama nosyonu üzerinden kalp sözcüğü çokça kullanılmaktadır (Esen, 2011). "Yeryüzünde dolaşmıyorlar mı ki ibret almış kalplere yahut işitmiş kulaklara sahip olsunlar! Şu bir gerçek ki gözler körleşmez fakat gögü̈lerdeki kalpler körleşir." (Kur'an-1 Kerim 22:46) Bu ayetten de anlaşıldığı gibi Kur'an-1 Kerim'de geçen kalp lafzı akıl ile bağlantılı olarak kullanılmıştır. Ayeti incelemeye aldığımız takdirde buradaki ibret lafzıyla görülen duyulan şeyleri değerlendirmenin kastedildiği anlaşılmaktadır (Diyanet İşleri Başkanlığı [DİB], 2007: 3/739). İbret kavramı, kendi içerisinde durumun farkına varma, anlama ve çıkarımda bulunma aşamalarını barındırmaktadır. $\mathrm{Bu}$ aşamalar da eleştirel düşünmenin içerisinde bulunmaktadır (Söylemez, 2016).

Turkish Academic Research Review - Türk Akademik Araştırmalar Dergisi https://dergipark.org.tr/tr/pub/tarr 
1096 Eleştirel Düşünme Eğiliminin Dindarlık Üzerine Etkisi: İlahiyat Fakültesi Öğrencileri Örneği

Kur'an-1 Kerim düşünme üzerinde çokça durmakta ve düşünceye insanları teşvik ederken birbirinden farklı kavramlar kullanmaktadır. Zikr/tezekkür, fikr/tefekkür, tedebbür, fikh/tefakkuh ve istinbat sözcükleri, Kur'an-1 Kerim'de geçen düşünme eylemiyle ilişkili bazı kavramlardır. Anlamları birbirlerine yakın olmasına rağmen bu kavramlar arasında ince farklılıklar mevcuttur. Tezekkür: bilinen şeyleri sürekli hatırda tutma ve zihindeki anlamlar üzerinde düşünme; tefekkür: bir konu üzerinde çaba göstererek, emek harcayarak bilme, düşünme; tedebbür: bir şeyin sadece görünen kısmı üzerine değil görünmeyen derin manaları üzerinde de düşünme; tefakkuh: dinde anlayış sahibi olma, bilinenden hareketle bilinmeyene ulaşmak için çaba sarf etme; istinbat: delillerden hareketle yeni bir bilgi ortaya çıkarma anlamına gelmektedir (Bilgiz, 2012). Kur'an-1 Kerim'in bu kavramlara yer vermesi, Akletmez misiniz? (Kur'an-1 Kerim 2:44), Hala düşünmüyor musunuz? (Kur'an-1 Kerim 37:155), Düşünüp öğ̈̈t almayacak mısınız? (Kur'an-1 Kerim 32:4), gibi telkinlerde çokça bulunması insanı düşündürmeye teşvik ettiğini göstermektedir. Yine bu kavramlar incelendiğinde insanın, derinlemesine bir düşünmeye yönlendirildiği görülmektedir.

İslam düşünce geleneğinde önemli bir yer tutan Maturidi'ye göre ise sağlam din, delillere dayanan dindir. Düşünme olmadan Allah'ın birliğinin, O'nun idaresinin, ilminin ve hikmetinin, öldükten sonra dirilmenin, O’nun kudret ve gücünün manasını anlamak mümkün değildir. Maturidi düşünme faaliyetini aşamalı bir şekilde ele alarak önce duyu organlarından gelen verilerin farkına varılması akabinde bu verilerden sonuçlar çıkarılması sonunda ise bu verilere dayanarak yeni ürünlerin oluşturulması şeklinde sıralar (Korlaelçi, 1987). Rasyonel alemden irrasyonel aleme geçişi bu şekilde sağlar. Görüneni algılayıp onun üzerine düşünerek görünenden görünmeyene, somuttan soyuta bir yol izler.

\subsection{Dindarlık}

İnsanların dini algılamaları ve algıladıkları şeyi kültürel ortamda hayata yansıtmaları farkl11ık göstermektedir (Köse ve Ayten, 2015: 111). Dindarlık kavramı da dinin algılanış biçimiyle yakından ilişkilidir (Kızılgeçit, 2011: 84). Algılayışa bağlı olarak bireyin kendisini dine veriş derecesi, dinî hayatı yaşamadaki dikkat ve yoğunluğu da farklılık göstermektedir (Doğan, 2014: 13). Bu farklılıklar ise dindarlığın çeşitli biçimlerde tanımlanması ve tipleştirilmesi şeklinde netice vermektedir. Dindarlı̆̆ın ifade edilmesinde farklı yaklaşımlar söz konusu olmakla birlikte araştırmada bireyin dindarlık düzeyi belirlenirken iç güdümlü/içsel dini yönelim/deruni dindarlık/intrinsic religiousness şeklinde ifade edilen dindarlığın derinlemesine boyutları dikkate alınmıştır. Zira din psikolojisi alanında en yaygın kullanılan 
dindarlık tiplemesinin Allport'un geliştirdiği içgüdümlü (intrinsic) ve dışgüdümlü (extrinsic) dindarllğa dayandığı görülmektedir (Gürses, 2010: 25).

Adorno vd.'nin, (2011) önyargı ile ilişkili olarak tespit etmiş oldukları özelliklerden biri de otoriteryen kişiliktir. Çalışmada dini amaç olarak değerlendiren bireylerin haricinde onu bir araç olarak görme eğilimine sahip bireylerin de olduğu ortaya konulmuştur (Adorno, 2011: 247; Karaca, 2017: 91; Kandemir, 2016: 22). Yapılan bu tespitlere Allport'un, dinin bir önyargı oluşturabileceği gibi, oluşmuş olan önyargıyı da değiştirebileceği şeklindeki paradoksal ifadesi de eklenmiştir (Kandemir, 2016: 23). Allport, din ile önyargı arasındaki ilişkiyi açılayabilmek amaciyla, önyargı ile ilgili teorisinde 1950 ve 1960 'lı yıllarda kilise üyelerinin, böyle bir üyeliği bulunmayanlardan daha önyargılı olduklarını gözlemlemesi sonucu düşmüş olduğu çelişkiyi açıklamak için bu kavramı bağımsız bir değişken olarak kullanmış ve içsel dindarlıktan bir yönelim olarak bahsetmiştir (Karaca, 2017: 91).

Allport öncelikle "olgunlaşmış ve olgunlaşmamış din" tabirlerini kullanmış sonrasında bu kavramları "iç güdümlü dinî yönelim ve diş güdümlü dinî yönelim" kavramlarıyla değiştirmiş̧ir. (Kandemir, 2016: 23). Allport gibi birçok araştırmacı da içsel ve dışsal dindarlık kavramlarını birer motivasyon olarak değerlendirmiş̧ir (Karaca, 2017: 91). Allport'a göre dini hayatın en önemli yanı dini duygunun kaçınılmaz bir parçası olan dini tecrübe olup "mutlak bağlllık hissi" de bu tecrübenin en ayırt edici özelliğidir (Karacoşkun, 2019: 54). Bu kapsamda dindarlığın ortaya konulmasında en önemli özellik Allport'a göre dindarlığın derinlemesine boyutlandırılmasıdır. Dinin etki ve fonksiyonlarını ön plana çıkaran bu yaklaşım, tamamen niyet faktörü üzerinde yoğunlaşmaktadır (Karaca, 2017: 92). Allport'un eserlerinde çokça tekrarlanan "dlş beklentiye yönelik dindarlar dinini kullanır, deruni dindarlar dinini yaşar" tümcesi konuyu kısa, açık ve anlamlı bir şekilde ortaya koymaktadır (Kayıklık, 2018: 224). Araştırmada kullanılan İçsel Dinî Motivasyon Ölçeği'nin "Dinimi bütün günlük işlerimin üzerinde tutmaya azami gayret sarf ederim." şeklindeki 5. maddesi bu noktaya dikkatleri çekmektedir. Teoloji terminolojisine göre, dış güdümlü dindarlık eğilimine sahip bireyler kendi benliklerini bırakmaksızın Tanrı’ya yönelmektedir. İç güdümlü dindarlık eğilimine sahip olan bireyler ise temel motivasyonların dinlerinde bulmakta ve dinlerini gerçek manada yaşamaktadır (Karayiğit, 2017: 62).

Dindarlığın derinlemesine boyutlarına yönelik yapılan araştırmalar içsel ve dışsal güdülenmenin birbirinden bağımsız olduğunu ve tek bir boyutun zıt kutupları olmadığını ortaya koymaktadır. Bu kapsamda yapılan diğer analizler ise içsel ve 
1098 Eleştirel Düşünme Eğiliminin Dindarlık Üzerine Etkisi: İlahiyat Fakültesi Öğrencileri Örneği

dışsal güdülenmelerin dik doğrusal (orthogonal) olduğunu göstermektedir (Cirhinlioğlu, 2014: 63; Doğan, 2014: 24). Ayrıca iç güdümlü inanca sahip bireyler, dış güdümlü inanca sahip olanlara göre psikolojik açıdan daha uyumlu gözükmektedir (Gürses, 2010: 31; Kızılgeçit, 2011: 90).

Kızılgeçit tarafından iç güdümlü dindarlık, "bireyin yaşamsal amacını dinde bulması, dini ilke ve pratikleri içselleștirmesi ve dini, hayatında dışsal bir kaygı taşımadan tam olarak yansıtma çabası" şeklinde tanımlanmaktadır (Kızılgeçit, 2020: 173). İç güdümlü dindarlıkta kişi, motivasyonu bizzat dinin kendisinde bulur (Köse ve Ayten, 2015: 115). Bireyin dini inançlarına gerçek ve temelden adanmışlığı ve bu adanmışlığın zaman ve durum karşısında değişmemesi iç güdümlü dindarlıkta görülür (Cirhinlioğlu, 2014: 61; Kızılgeçit, 2011: 88). Bu tip dindarlar için diğer bütün ihtiyaçlar, arzular, güdüler ne kadar güçlü olursa olsun olabildiğince az ehemmiyetli olarak kabul edilir ve mümkün olduğu kadar dini inanç ve hükümlerin güdümünde bırakılır. İç güdümlü eğilim basit bir uyma şekli olmadığı gibi ne bir dayanak ne bir sakinleştirici ne de mevki kazanmak için bir çaba sarf etme eylemidir. Bütün ihtiyaçlar, sürekli yerine getirilmekte olan dini davranışların boyunduruğu altındadır (Kızılgeçit, 2011: 88). Özellikle dikkatleri çekmek istediğimiz nokta iç güdümlü dindarlığın oluşumunda etkin olan anlamdır. İç güdümlü dindarın hayatını dini üzerine şekillendirirken dini anlamlandırma süreci, dini anlama süreci eleştirel düşüncenin aktif olduğu süreç olarak değerlendirilebilir.

Dini inancın motivasyon kaynağına dikkat çekmek amacıyla geliştirilen ve psikolojik bir kavram olan "içsellik" kavramı, biyolojik bir kavram olan "hazım" kavramına benzetilmektedir (Karaca, 2017: 91). Tıpkı dışarıdan alınan bir yiyeceğin hazmedilmesi sonucu o yiyeceğin vücudun tüm hücrelerine ulaşması gibi bireyin herhangi bir şeye inanması ile içselleştirilen bir inanç da psikolojik bünye tarafından içselleştirildiği andan itibaren o bünyenin çok önemli bir parçası haline gelmektedir (Kızılgeçit, 2011: 88). Bu kapsamda dini inançlar da birey tarafindan bu şekilde içselleştirilebilmekte ve sahiplerinin kişiliklerinin ve yaşamlarının önemli bir parçası haline gelmektedir (Karaca, 2001: 193). Bireyin din ile ilk buluşmasından sonra onu kendisine mal etmesi, dini kendisiyle bütünleştirmesi din hakkında derin düşünmeyle oluşacak bir durum olarak gözükmektedir.

İç güdümlü dindarlar için din benliğin hizmetinde olması sebebiyle dıştan gelen bir değer olmayıp İlahi Varlığın iradesine uygun olarak kişiyi değişime zorlayan içten doğma bir değerdir. Müsamaha, saygı, başkalarına karşı iyi niyet, dini emir ve yasaklara uyma ve ibadetlerde devamlılık gibi dinî vecibeler özenle yerine 
getirilerek gözlemlenebilir ve ihlaslı bir hayat tarzı yaşanmaya çalışılır. "Iç̧ten doğma", "derunileşmişs", "yaşanılan” veya "şahsileşmiş" bu tip dindarlık, karşılık beklemeden kendini toplum hizmetine adayanlarda ve kendini inandığ esaslar uğruna feda edenlerde daha belirgin olarak görülür (Hökelekli, 2013: 77; Kızılgeçit, 2011: 89). İnsanın iç güdümlü dindar olabilmesi için öncelikle şüpheden imkân dahilinde arınması gerekmektedir. Şüpheyi giderecek en temel vasıta düşünme kabiliyetidir. Neye niçin inandığını bilen insan adım adım şüpheden uzaklaşarak kendisine yönelebilmektedir. $\mathrm{Bu}$ yönelim sonucunda da dine içsel olarak yakınlaşmaktadır.

Allport'a göre iç güdümlü dindarlar dinî inanç ve emirlerle uyum içindedir ve hayatı inançla bütünleştirip içselleştirmiştir. Ayrıca bu boyutta dindarlar, din karşısında diğer ihtiyaçlarına daha az önem verirken ana güdülerini dinde bulmakta ve (Allport, 2016; Doğan, 2014: 25) inanmış oldukları dinî inanç ve emirlerle uyumlu hale getirmektedir (Allport, 2016; Kandemir, 2016: 23). Ayrıca iç güdümlü dindarlar gerçek mümin olarak nitelendirilmektedir. Dinlerini ciddiye almakta ve yapıp etmelerinin, zihniyetlerinin, var olana bakış açılarının, hayat tarzlarının ve olaylar karşısında pozisyon alış biçimlerinin yegâne referans kaynağını din oluşturmaktadır (Gürses, 2010; Doğan, 2014: 25). Dini ciddiye almanın göstergesi olarak din hakkında düşünme, din ile düşünme ve din için düşünme faaliyetleri sıralanabilmektedir. Bu kapsamda din, bireyin kişiliğinin oluşmasında olduğu gibi canlı ve cansız bütün varlıklarla ilişkisini de belirleyen en önemli motivasyon kaynaklarındandır (Kandemir, 2014: 24). Sadece insanın Yaratıcı ile ilişkisini değil çevresiyle olan ilişkisini de düzenleyen din ancak anlaşıldığı takdirde bunu yapabilmektedir.

Allport'a göre olgunlaşmış dini his, iç güdümlü dindarlığa zemin hazırlamaktadır. Dini hissin olgunlaşmasında; dini hissin farklılaşması, dinamik yapısıyla birey için geleceğe yönelik yeni amaçlar sunması, bireyi yüksek ahlaki ideallere yönlendirmesi vb. kriterler yer almaktadır (Allport, 2016: 147; Karayiğit, 2017: 62). Olgunlaşma kavramı belirli bir yetkinlik seviyesini gösterir ki bunun içerisinde bilişsel yetkinlik de bulunmaktadır. Seçme, analiz etme, karar verme, doğruyu arama, yanlışı fark etme vs. pek çok özelliği içeren eleştirel düşünme becerisiyle birey geleceğine daha iyi yön verebilmektedir. Bu açıdan yeni amaçlar belirleyen birey hem dini ile hem de düşünme becerisiyle bunu gerçekleştirmektedir.

İslam dininin temel kaynakları incelendiğinde iç güdümlü dindarllğın; tevhid, niyet ve samimiyet kavramlarıyla ifade edildiği görülmektedir. Müslüman'ın bütün

Turkish Academic Research Review - Türk Akademik Araştırmalar Dergisi https://dergipark.org.tr/tr/pub/tarr 
1100 Eleştirel Düşünme Eğiliminin Dindarlık Üzerine Etkisi: İlahiyat Fakültesi Öğrencileri Örneği

amellerinde Allah'ın rızasını kazanmaya çalışması ve yegane amacının Yaratıcının memnuniyeti olması gerektiği Kur’an-1 Kerim ve hadis-i şeriflerde vurgulanmıştır.

\subsection{Eleştirel Düşünme ile Dindarlık Arasındaki İlişki}

"Din ve insan arasındaki ilişki, bilinçli ve iradeli bir teslimiyete dayanır. Bu teslimiyet, bireyi büyük bir resmi tamamlayan önemli bir parçaya dönüştürür.', (Düzgün, 2020). Din ve insan arasındaki ilişki olarak tanımlanan dindarlık, insanın bilinçli teslimiyeti sonucu oluşmalıdır. Bilinçli teslimiyet kavramı manidar bir tespittir. Araştırmamızın mihenk taşı olabilecek kavramlardan birisidir. Teslimiyet kavramı pasif içerikli olarak boyun eğme, inanma anlamlarına gelmektedir. Ancak bilinçli teslimiyet neye niçin boyun eğdiğini bilen insanın eylemidir. Düşünen, eleştirel düşünen insanın eylemidir.

Bilinçli teslimiyet kavramı çerçevesinde; Karaca (2017: 134), imanı oluşturan unsurlar arasında bilişsel ve iradi unsurlardan bahsetmektedir. Bilişsel unsur, insanın düşünce gücüne tekabül etmekle kişinin kendisinin ve çevresinin varlığının farkına vararak akıl yürütme faaliyetini içermektedir ki burada bilince vurgu dikkati çekmek istediğimiz husustur. Kişinin diniyle ilgili bilgileri sorgulaması, anlaması, ilişki kurması ve gerektiğinde kullanmasını sağlamaktadır. "Iman, basit bilişsel bir olgu olmayıp yüksek düzeyde bir farkındalık gerektirmektedir.” (Karaca, 2017). İmanın bağlanma, gönül verme gibi duygusal boyutları da teslimiyet kavramıyla özdeşleşmektedir. İman bilinçli teslimiyettir. Ne bilinç olmadan olur ne de teslimiyet olmadan olur. İman için hem bilinç hem de teslimiyet gereklidir.

Dindarlık ve eleştirel düşünme arasındaki ilişki, Din Psikolojisi alanyazınında dini gelişim süreçleri ve dindarlığın boyutlarından bilişsel boyutlar, bilgi boyutu ve iç güdümlü dindarlık boyutu içerisinde ele alınabilmektedir. Dindarlığın tanımında insanın din ile karşılaşması, dini algılaması ve dini hayatına yansıtması temaları bulunmaktadır (Kızılgeçit, 2017; Karaca, 2017; Köse ve Ayten, 2015).

Bilişsel boyutları ele alırken dini gelişime kısaca değinmemiz insanın yaşam serüvenindeki din nosyonunu anlamamızı ve din ile eleştirel düşünme arasındaki bağı ortaya koymamızı kolaylaştıracaktır. Din ile karşılaşma kişinin istek ve iradesi dışında gerçekleşebileceği gibi bir arayışın sonucu da olabilmektedir. Spesifik bazı durumlar dışında tüm insanlar belli bir dini inancın içine doğmaktadır. Dolayısıyla dinle ilk karşılaşma çoğunlukla istem dışıdır. Çocukluk dönemi dini gelişim incelendiğinde bu döneme has bazı özellikler olduğu görülmektedir. Ailesinde ve çevresinde din ile karşılaşan çocuk taklitle, oyunla dini yaşantıyı kendi dünyasına dahil etmektedir. Din ile karşılaşmadan sonra algılama dediğimiz tema; insanın artık 
kendisinin ve çevresinin farkına vardığı, soyut düşünme becerileri kazandığı ergenlik döneminde meydana gelmektedir. Ergenlik dönemi sorgulamanın yoğun olduğu bir evre olup dini uyanış ve dini gelişim yaşları olarak da kabul edilmektedir. Sorgulamaların başladığı, bilişsel gelişimin yeterli seviyeye gelmesiyle eleştirel düşüncenin ortaya çıkmaya imkan bulduğu ve şüphelerin kol gezdiği bu dönemde gençlerin dini algılamaları bilişsel özelliklerini ne kadar kullandıklarıyla doğru orantılı olarak çeşitlenmektedir. Şüpheler ve sorgulamalar sonucunda insan dine ulaşabildiği gibi dinden de uzaklaşabilmektedir. Ya da bu dönemde sorular cevapsız bırakılarak din direkt ret veya kabul edilebilmektedir.

İnsanın hayatı kümülatif olarak düşünüldüğünde ergenlik dönemi keskin virajların olduğu, gel-gitlerin çokça yaşandığı kritik dönemlerdendir (Karaca, 2016: 93-121). $\mathrm{Bu}$ dönemde kimlik krizi yaşayan ve kendine bir kimlik oluşturma çabası içerisinde bulunan ergen, kimliğini oluştururken eleştirel düşünerek önceden kabul ettiği veya reddettiği değerleri sorgulamalı ve yaşanan bunalımlara vaktinde cevaplar bulmalıdır. Karaca'nın dini gelişim modelinde de sorgulama ve tahkik olarak belirtilen 17-22 yaş aralığını kapsayan bir aşama bulunmaktadır. Bu aşamada insan hayatın anlamına yönelik derin bir sorgulamaya, geçmiş bilgilerinden şüphe etmeye ve yeni öğreneceği bilgilerde kanıt aramaya başlar. Dini hakkında araştırma yaparak çeşitli paradokslara çözüm bulmaya çalışır. İşte bu aşamada metafizik boyutla karşılaşarak sezgi ve duygularıyla teslimiyet ve bağlanma hissi açığa çıkar (Karaca, 2016: 135-169).

İnsanın dinini tanıması, onunla hayatı anlamlandırması eleştirel düşünmeyle sağlanabilmektedir. Ancak tek başına eleştirel düşünce yeterli değildir. Çok kompleks bir yapıya sahip olan insan, duygularından bağımsız düşünülemediği gibi bilişten de bağımsız düşünülmemelidir. Ergenlikten sonraki gelişim dönemi yetişkinliktir. $\mathrm{Bu}$ dönemde olgunlaşma, durulma, inançlar üzerinde yeniden düşünme, kendini tanıma, kendiyle yüzleşme gibi insanı düşünmeye sevk edecek birtakım durumlar oluşmaktadır. Bu dönemde oluşan düşünceler genel itibariyle önceki dönemde karar verilen ya da bu dönemde karar verilen düşünceler üzerine yoğunlaşma şeklindedir. Ancak yetişkinlik içerisinde orta yaş krizi denen bir dönemin varlığı malumdur. $\mathrm{Bu}$ dönem kişinin kendi kendisiyle hesaplaşma dönemidir. İnsan geçmişe bakarak ya mutlu olacak ya da pişman olacaktır. Bu krizin sonucu olarak orta yaş döneminde de keskin dönüşler yaşanabilmektedir (Hökelekli, 2013: 284-285). Hayatın sonuna doğru yaşlılık dönemine geçiş yapılır. Bu dönemde daha sakin ve istikrarlı bir hayat gözlenmektedir. Önceki dönemlerin sentezi olarak görülen yaşlılıkta ölümle yüzleşme, dönemin temel özelliklerindendir. Ölümü

Turkish Academic Research Review - Türk Akademik Araştırmalar Dergisi https://dergipark.org.tr/tr/pub/tarr 
1102 Eleştirel Düşünme Eğiliminin Dindarlık Üzerine Etkisi: İlahiyat Fakültesi Öğrencileri Örneği

yakından hisseden yaşlılar dine karşı daha 1lımlı bir tavır sergilemektedir (Karaca, 2016: 215-242). Ergenlikte başlayan düşünme faaliyeti hayatın sonuna kadar devam etmekle birlikte yaşlılığa doğru bu düşünce faaliyetinde bir düşüş olduğu söylenebilmektedir. Eleştirel düşünce şüphe etme, sorgulama, anlama, derin düşünme ve karar verme bağlamında ergenlik ve yetişkinlik dönemlerinde kendisini göstermektedir. Bir insan eleştirel düşünme becerisine sahip olmadan da dindar olabilmekle beraber neyi ne için yaptığını tam olarak çözümleyememekte ve yaptığı şeyin tam olarak farkında olamamaktadır. Dinin insanın hayatına katması gereken anlamı-insan anlamak istediğinde oluşturacaktır ki- sağlayacak olan en önemli fenomen eleştirel düşünme eğilimidir.

Dindarlık boyutlarıyla eleştirel düşünme arasındaki ilişkiye baktığımızda eleştirel düşünmenin dindarlık boyutları içerisinde önemli bir yer tuttuğunu söyleyebilmekteyiz. Stark ve Glock'un ortaya koyduğu beş temel boyuttan birisi bilgi boyutudur. $\mathrm{Bu}$ boyut, insanın neye inandığını bilmesi ve dinin gerekliliklerini yerine getirmesi için asgari düzeyde bilgi sahibi olmasını ifade etmektedir. Sağlam bilgi önemlidir ancak yeterli değildir. Bilginin inançla doğrudan bağlantısı olmakla beraber her bilenin inançlı olmadığı da vakidir. Bilgi kişinin inancını anlamasını ve kavramasını kolaylaştırmaktadır. Dini üzerine bilgi sahibi olan bir insanın dinine uygun davranması kuvvetle muhtemeldir (Karaca, 2017: 99-101). Burada bilgiyi elde etmekten ziyade bilgi ile dini anlamak, dini tanımak ön plandadır. Bilginin işlenmesi, kişinin inancını bilgisiyle desteklemesi inancın hayata aktarımını kolaylaştırmaktadır. Burada dikkat edilecek bir diğer husus kişinin bilgiyi nasıl elde ettiğidir. İnsanın bilgi edinme sürecinde aktif olması bilgiyi işlevsel bir hale getirir. Dolayısıyla bilginin oluşumunda eleştirel düşünebilmek doğru bilgileri elde etme ve elde edilen bilgileri kullanma açısından önemlidir. Kayıklık (2018) dindarlığı bilişsel süreçler ve duygusal süreçler boyutu olmak üzere iki temel boyutla incelemektedir. Dini algılamak, öğrenmek, sorgulamak, anlamak, seçmek vb. özellikler bilişsel süreçlerin sonucudur. Bilişsel süreçler sadece dinin seçim aşamasında değil dini seçtikten sonra yaşama, anlama, sorgulama aşamasında da aktiftir. Özellikle dinini ve inancını delillendirmek isteyen insan bu boyutla düşüncelerine yön verir. Din olgusu bilişten bağımsız düşünülemediği gibi tabi ki duygudan da bağımsız değildir (Kayıklık, 2018). Bilişsel ve duygusal süreç boyutlarını birbirinin tamamlayıcısı olarak görmek dindar bireyi anlamak açısından önemlidir.

Gelişimsel dindarlık boyutları içerisinde Gazali (1975: 34-35)'nin ortaya koyduğu taklit, ilim ve zevk boyutları bulunmaktadır. İnsanın taklitle başladığı dindarlık 
serüveni ilim ile devam etmekte bu iki aşamadan sonra ise dindarlığın son boyutu olan zevk boyutuna geçilmektedir. Gazali, özellikle ilim boyutu üzerinde çokça durmuş ve bilginin şüpheden tamamen arınık olması gerektiğini ifade etmiştir. Görüldüğü gibi Gazali’nin sınıflandırmasının merkezinde de düşünce vardır. Bu bilgilere paralel olarak Allport 'un iç güdümlü ve dış güdümlü dindarlık boyutlarında da buna benzer bir mantık söz konusudur. Dinin araç olduğu bir dindarlıkta din üzerine düşünme söz konusu dahi değildir ancak dinin amaç olarak belirlendiği bir dindarlıkta kişinin amacı hakkında bilgi sahibi olmaması, amacı üzerine düşünmemesi yine imkânsız görünmektedir. Gelişimsel dindarlık çerçevesinde Meadow ve Kahoe (1984)'nin modeline göre dış güdümlü dindarlık en alt basamakta iç güdümlü dindarlık ise üçüncü basamaktadır. Bu modele göre olgunlaşmış dindarlığa ulaşmak için dış güdümlüden başlayarak kademe kademe ilerleme kat edilmelidir. Bu modelin en ileri en üst seviyesini ise özerk inanç oluşturmaktadır. Özerk inancın iç güdümlü inançtan temel farkı daha düşünsel ve sorgulayıcı bir yapıya sahip olmasıdır. İç güdümlü dindarlığı da dış güdümlü dindarlıktan ayıran fark dinin ulaşılacak yegâne amaç olmasıdır ki bu da dini anlama ve algılama sayesinde gerçekleşecektir (Karaca, 2017). Bu bilgiler 1şı̆̆ında eleştirel düşüncenin inancı, taklitten tahkike, dış güdümlüden iç güdümlüye, iç güdümlüden özerke ulaştırmada aktif rolü olduğu söylenebilmektedir.

Topçu, düşünmeye özellikle değer atfetmektedir. Ona göre düşünme bilgiyi alma, depolama gibi bir işlem değildir, bunun çok ötesinde bilgiyi işleme kabiliyetidir. “Düşünmek hatırlamak değil, yaratmaktır.” diyerek düşünmenin yeni bir şeyler üretme boyutuna dikkat çekmiştir. Aksi halde herkesin aynı şeyleri söylemesi kaçınılmazdır ki bunun sonucunda insan, papağan konumuna düşmektedir (Topçu, 2011: 42-51). Topçu, Müslümanlık-dindarlık bağlamında kendi aklıyla düşünemeyen insanların hiçbir zaman gerçek dindar olamayacaklarını vurgulamaktadır.

\section{Amaç ve Önem}

Araştırmanın temel amacı İlahiyat Fakültesi öğrencilerinde eleştirel düşünme eğilimleri ile dindarlık düzeyleri arasındaki ilişkiyi içsel dinî motivasyon ölçeği ve eleştirel düşünme eğilimi ölçeği kullanarak tespit etmektir. Bu çerçevede; "eleştirel düşünme eğiliminin motivasyonel dindarlık düzeyini yordamaya katkısl” temel amacı haricinde "örneklem grubunda eleştirel düşünme eğilimi düzeyi alt boyutlarıyla motivasyonel dindarlık arasında anlamlı bir ilişki var mıdır? ” sorusuna da cevap aranmıştır. Ayrıca sosyo-demografik değişkenlere göre bağımlı değişkenlerdeki farklılaşmalar da incelenmiştir.

Turkish Academic Research Review - Türk Akademik Araştırmalar Dergisi https://dergipark.org.tr/tr/pub/tarr 
1104 Eleştirel Düşünme Eğiliminin Dindarlık Üzerine Etkisi: İlahiyat Fakültesi Öğrencileri Örneği

Bilgiye, gelişen teknolojiyle birlikte kolay bir şekilde ulaşabildiğimiz ve her türlü bilginin kaynağının belli olmadan sosyal mecralar aracılığıyla ortaya konulabildiği çağımızda bireyin bir hakikati kabul etmeden önce mihenge vurması gerçekten önem arz etmektedir. Toplumsal anlamda araştıran, sorgulayan, delillendiren bir bilinç oluşturma bağlamında bu çalışmanın topluma katkı sunması beklenmektedir. Yine dindarlık ve eleştirel düşünme eğilimi arasındaki ilişki bize çeşitli yorumlar yapabilme imkânı sağlayacaktır.

Eleştirel düşünme becerisiyle bireyin, başta kendisini anlaması olmak üzere çevresindeki değişimi ve başkalarının davranışlarını etkilemesi noktasında onların duygu ve düşüncelerini anlayabilmesi hem başarıyı yakalayabilmesi hem de çağımızın getirdiği bilgi kirliliğinde sözün altın mı, gümüş mü, bakır mı olduğunu irdeleyebilmesi açısından değer kazanmaktadır. $\mathrm{Bu}$ bağlamda dinini eleştirel düşünme bağlamında ele alan insanın dini ile daha ciddi bir iletişim kurması dindarlığın oluşumu için önemli görülmektedir. Ayrıca bu araştırmanın sonuçları yeni araştırmalara ilham olabilmekle beraber özellikle İlahiyat eğitimi içerisinde eleştirel düşünmeye farklı bir bakış kazandırabileceği değerlendirilmektedir.

Din psikologları tarafından dindarlık üzerine yapılan çalışmalarda dinin sorgulama, bilgi ve bilişsel boyutlarının dindarlığı etkilediği ortaya konulmuştur. Özellikle motivasyonel dindarlık konusunda bir kısım psikologlar içgüdümlü dindarlığın, dış güdümlü dindarlıktan ayrıldığı noktanın dinin her açıdan anlamlandırılabilmesi, dinî değerlerin her yönüyle içselleştirilebilmesi ve yaşamın trajedi ve çelişkilerinin ortaya çıkardığı varoluşsal problemlere dinî literatürde bir cevap bulunabilmesi olduğuna vurgu yapmaktadır. Sonuç olarak bireyin dindarlık düzeyini belirleyen en önemli etkenlerin akıl, sorgulama, anlamlandırma, içselleştirme olduğu dikkate alındığında bireyin eleştirel düşünme becerisine sahip olmasının tartışmasız olarak dindarlığını etkileyeceği değerlendirilmektedir.

Konuyla ilgili literatürde, İlahiyat Fakültesi (İlahiyat Bölümü) ile Din Kültürü ve Ahlak Bilgisi bölümü öğrencilerinin eleştirel düşünme eğilimlerinin tespiti ve karşılaştırılmasına yönelik çalışmalar yer almaktadır. Türkiye'de dindarlık ve eleştirel düşünme eğilimi ilişkisini doğrudan konu edinen M. E. Duran (2020) tarafından gerçekleştirilen bir araştırma bulunmaktadır. Ancak söz konusu araştırma, bireylerin eleştirel düşüncelerinin gelişip gelişmemesinde dinin nasıl bir etkisinin olduğu sorusuna cevap araması açısından dindarlığın eleştirel düşünme eğilimini yordaması noktasını ele almıştır. Gerçekleştirilen çalışmada farklı dindarlık ölçeği 
kullanılmakla birlikte eleştirel düşünme eğiliminin dindarlığı yordayıp yordamadığı hususu üzerinde durulacaktır (Şekil-1).

\section{Yöntem}

\subsection{Araştırma Deseni}

Araştırma, Atatürk Üniversitesi İlahiyat Fakültesi’nde öğrenim gören öğrencilerin eleştirel düşünme düzeylerinin dindarlıklarına etkisinin ortaya çıkarılmasını amaçlayan nicel bir araştırma olarak kurgulanmış ve ilişkisel tarama modeline göre tasarlanmıştır (Şekil-1).

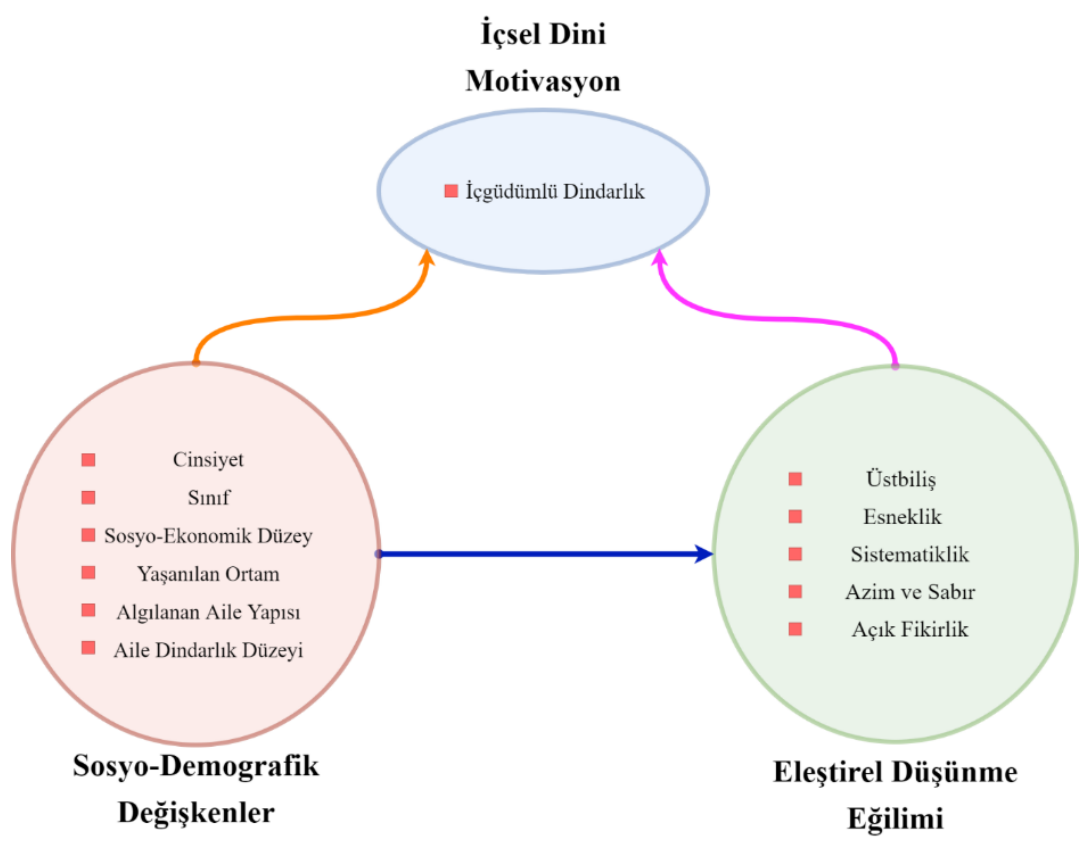

Şekil 1: Araştırma Modeli

\subsection{Evren ve Örneklem}

Çalışmanın evrenini, 2020-2021 akademik yılında Atatürk Üniversitesi İlahiyat Fakültesi'nde öğrenim gören öğrenciler oluşturmaktadır. Bu öğretim yıllarında fakültede hazırlıkta 205,1 . sinıfta 226,2 . sinıfta 216 , 3. sinıfta 226 ve 4 . sinıfta 226 öğrenci olmak üzere toplamda 1.099 öğrencinin öğrenim gördüğü www.yokatlas.yok.gov.tr adresinden belirlenmiştir. Krejcie ve Morgan (1970) tarafindan oluşturulan örneklem hesaplama çizelgesinde .05 hata payıyla evrendeki 1100 katılımcı için ortalama 285 kişilik örneklem sayısının aşılması gerektiği dikkate alınarak çalışmanın örneklemi 296 kişiden oluşturulmuştur. Örneklem seçiminde basit seçkisiz örnekleme yöntemi kullanılmıştır. Örneklemin cinsiyet

Turkish Academic Research Review - Türk Akademik Araştırmalar Dergisi https://dergipark.org.tr/tr/pub/tarr 
1106 Eleştirel Düşünme Eğiliminin Dindarlık Üzerine Etkisi: İlahiyat Fakültesi Öğrencileri Örneği

dağılımına bakıldığında erkek öğrencilerin oranı \%20,3 (n=60); kız öğrencilerin oranı ise $\% 79,7(n=236)$ olarak görülmektedir.

Tablo 1: Örneklemin cinsiyet ve sınıfa göre dağılımı

\begin{tabular}{llllll}
\hline & Erkek & Kız & & Toplam \\
& \% & n & \% & n & \\
\hline Hazırlık & 15,6 & 5 & 84,4 & 27 & $\mathbf{3 2}$ \\
& & & & & \\
\hline 1. Sınıf & 10,0 & 6 & 90,0 & 54 & $\mathbf{6 0}$ \\
\hline 2. Sınıf & 20,5 & 27 & 79,5 & 105 & $\mathbf{1 3 2}$ \\
\hline 3. Sınıf & 32,0 & 8 & 68,0 & 17 & $\mathbf{2 5}$ \\
\hline 4. Sınıf & 29,8 & 14 & 70,8 & 33 & $\mathbf{4 7}$ \\
\hline Toplam & $\mathbf{6 0}$ & & $\mathbf{2 3 6}$ & & $\mathbf{2 9 6}$ \\
\hline & & & & & \\
\hline
\end{tabular}

\section{3. Çalışma Grubuna İlişkin Veriler}

İlahiyat Fakültesi öğrencilerinin sosyo-demografik özellikleri ile ilgili bulgular Tablo-2'de ayrıntılı olarak sunulmuştur. Örneklemin cinsiyet ve sınıf bilgilerine ilişkin dağılımları ise Tablo-1'de gösterilmiştir.

Tablo 2: Örneklemin sosyo-demografik özelliklerine ait frekans analizi

\begin{tabular}{|c|c|c|c|}
\hline & Değişkenler & $\%$ & $\mathrm{n}$ \\
\hline \multirow{5}{*}{ Sosyo-ekonomik düzey } & Düşük & 5,8 & 17 \\
\hline & Ortanın alt1 & 7,7 & 23 \\
\hline & Orta & 61,8 & 183 \\
\hline & Ortanın üstü & 23,3 & 69 \\
\hline & Yüksek & 1,4 & 4 \\
\hline \multirow{2}{*}{ Aile dindarlık düzeyi } & Düşük & 1,7 & 5 \\
\hline & Ortanın altı & 2,4 & 7 \\
\hline
\end{tabular}




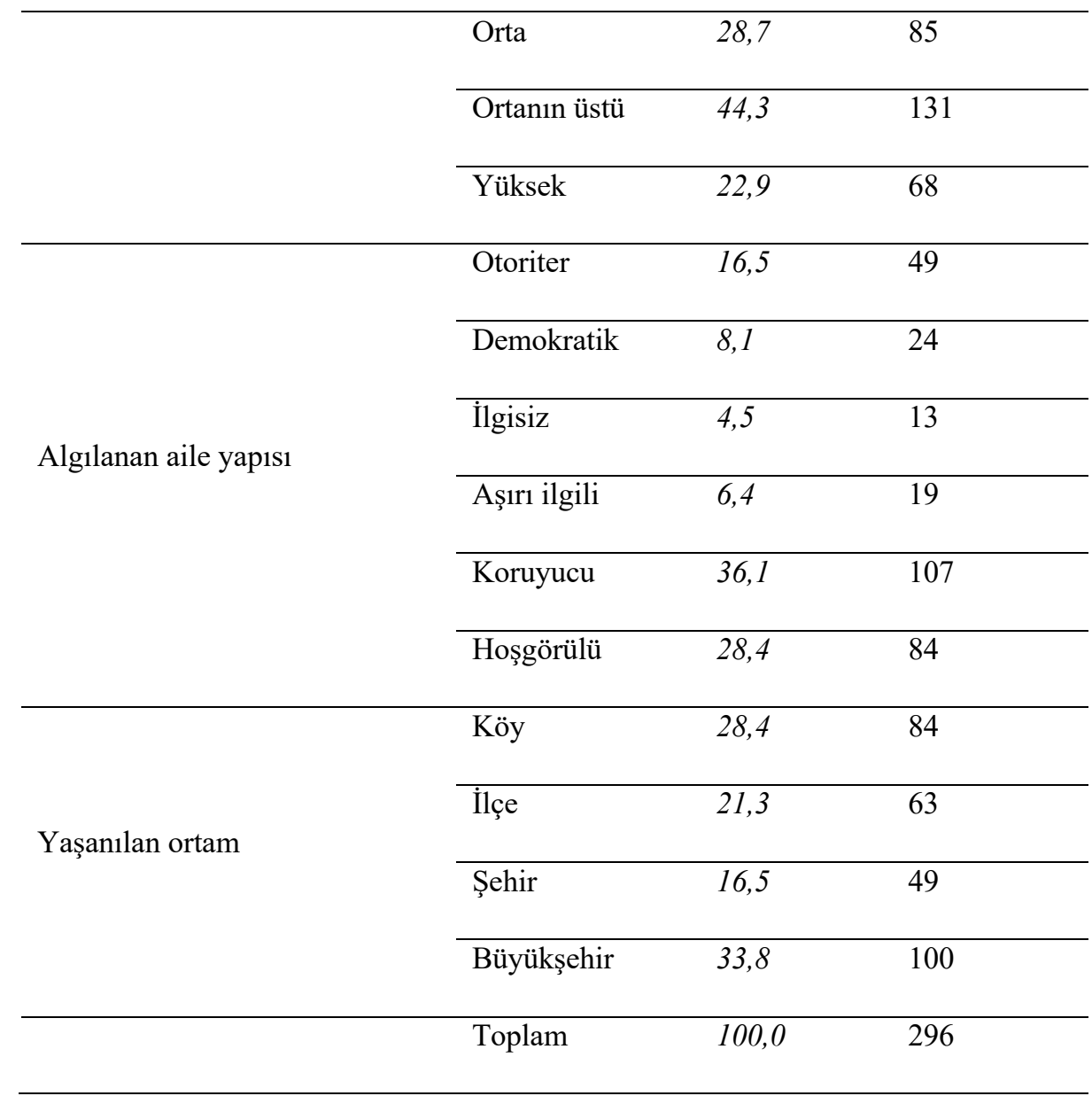

Araştırmaya katılanların algıladıkları sosyo-ekonomik düzeyleri \%5,8 (n:17) oranında düşük, \%7,7 (n:23) oranında ortanın altı, \%61,8 (n:183) oranında orta, \%23,3 (n:69) oranında ortanın üstü ve \%1,4 (n:4) oranında yüksek şeklindedir.

Katılımcıların ailelerine ilişkin algıladıkları dindarlık düzeyleri \%1,7 düşük (n:5), $\% 2,4$ ortanın altı (n:7), \%28,7 orta (n:85), \%44,3 ortanın üstü (n:131) ve \%22,9 yüksek (n:68) şeklinde farklılaşmaktadır.

Örneklem, algılanan aile yapısına göre \%16,5 otoriter (n:49), \%8,1 demokratik (n:24), \%4,5 ilgisiz (n:13), \%6,4 aşırı ilgili (n:19), \%36,1 koruyucu (n:107) ve \%28,4 hoşgörülü (n:84) şeklinde oluşmaktadır.

Katılımcıların üniversiteye başlamadan önce yaşadığı ortamın \%28,4’ünü (n:84) köy, \%21,3’ünü (n:63) ilçe, \%16,5’ini (n:49) şehir ve \%33,8’ini (n:100) büyükşehir oluşturmaktadır.

\subsection{Verilerin Toplanması}

Turkish Academic Research Review - Türk Akademik Araştırmalar Dergisi https://dergipark.org.tr/tr/pub/tarr 
1108 Eleştirel Düşünme Eğiliminin Dindarlık Üzerine Etkisi: İlahiyat Fakültesi Öğrencileri Örneği

Örneklem grubuna, 2020-2021 akademik yılının bahar döneminde www.google.com/forms aracılığıyla anket formu uygulanmıştır. Uygulama gönüllülük esasına dayalı gerçekleştirilmiştir. Uygulamanın sağlıklı olması amacıyla anket formu içerisinde boş ve tekrar eden sorulara yer verilmiştir.

Araştırma ile ilgili etik ve bilimsel yönden sakınca bulunmadığına ilişkin Atatürk Üniversitesi Sosyal ve Beşeri Bilimler Etik Kurul Başkanlığı’ndan 01.06.2020 tarihli, 4 oturum sayılı ve 32 karar nolu “Etik Kurul Onay Belgesi” alınmıştır.

\subsection{Veri Toplama Araçları}

Araştırmada Eleştirel Düşünme Eğilimi Ölçeği (EDE) ve İçsel Dini Motivasyon Ölçeği’nden (İDMÖ) oluşan anket formu, ölçme aracı olarak kullanılmıştır. Anketin ilk bölümünde katılımcıların kişisel özelliklerini (cinsiyet, sınıf, yaşamının büyük çoğunluğunu geçirdiği yerleşim birimi, algılanan sosyo-ekonomik durum, algılanan aile yapısı, algılanan aile dindarlık düzeyi) tespite yönelik sorulara da yer verilmiştir.

\subsubsection{Eleştirel Düşünce Eğilimi Ölçeği}

Semerci (2000) tarafından “Kritik Düşünme Ölçeği” adı altında tek boyutlu olarak geliştirilen ölçek, eleştirel düşünmenin farklı boyutlarının olması ve istatistiki yöntemlerin gelişmesi nedeniyle 2016 yılında revize edilmiş ve "Eleştirel Düşünme Eğilimi Ölçeği” adıyla 1081 kişilik öğrenmen adayları ve öğretmenlerden oluşan örnekleme uygulanmıştır (Semerci, 2016). EDE taslak ölçeği, oluşturulmaya başladığında literatürde var olan benzer ölçeklerin incelenmesiyle 150 maddeden oluşmuş ve uzman görüşlerine göre 102 maddeden oluşan bir soru havuzu hazırlanmıştır (Semerci, 2000). Ölçeğin revize çalışmasında 55 madde daha eklenmiştir (Semerci, 2016).

Son halini alan ölçek; üstbiliş (1-14. maddeler), esneklik (15-25. maddeler), sistematiklik (26-38. maddeler), azim ve sabır (39-46. maddeler) ve açık fikirlilik (47-49. maddeler) olmak üzere 5 boyuttan oluşmaktadır. 5'li likert tipi olarak hazırlanan ölçeğin puanlanması, tamamen katılıyorum (5), çoğunlukla katılıyorum (4), kısmen katılıyorum (3), çoğunlukla katılmıyorum (2) ve hiç katılmıyorum (1) şeklindedir. Ölçekten alınabilecek maksimum puan 245, minimum puan ise 49'dur. Toplam puan arttıkça eleştirel düşünebilme eğilimi de artmaktadır. Ölçek içerisinde olumsuz madde bulunmamaktadır (Semerci, 2016).

Ölçeğin içsel tutarlılık ölçütü olan Cronbach's Alpha katsayısı Semerci (2016) tarafından yapılan analizde .96, Gözüyeşil'in (2020) çalışmasında .97, Alkoç (2020)

Turkish Academic Research Review - Türk Akademik Araştırmalar Dergisi 
tarafından yürütülen araştırmada .94, Tunçer'in (2020) analizinde .96 ve Duran’ın (2020) çalışmasında .80 olarak hesaplanmıştır. Yapılan çalışmada ölçeğin tüm maddelerinin Cronbach's Alpha katsayısı .95 olarak tespit edilmiştir. Üstbiliş alt boyutunun .83 , esneklik alt boyutunun .85 , sistematiklik alt boyutunun .89 , azim ve sabır alt boyutunun .85 ve açık fikirlilik alt boyutunun .60 olmak üzere Cronbach's Alpha katsayıları hesaplanmıştır (Tablo-2).

\subsection{2. İçsel Dinî Motivasyon Ölçeği (İDMÖ)}

Dean Hoge tarafından geliştirilen ve Karaca tarafından Türkçe’ye standardizasyonu yapılmış olan 10 maddelik “İçsel Dinî Motivasyon Ölçeği ” nin 7 maddesi (1, 2, 3, 4, 5, 6 ve 7), "dinî inançlarım hayata bakış açımı belirler” maddesinde olduğu üzere olumlu cümle kalıbında, diğer maddeler (8, 9 ve 10) ise, "ahlâkî bir hayat yaşadı̆̆ım sürece neye inandığım o kadar önemli değil” maddesinde olduğu gibi olumsuz cümle yapısı şeklinde ifade edilmiştir (Karaca, 2001).

Ölçekte 5'li Likert tipi format kullanılarak ("1" Kesinlikle katılmıyorum, “2” Katılmıyorum, “3” Kararsızım, "4” Katılıyorum ve "5” Kesinlikle katılıyorum) şeklinde 1'den 5'e kadar, zayıftan kuvvetliye doğru puanlama yapılmıştır. Puanlamada, ölçeğe olumsuz cümle yapısında yerleştirilen maddelerin puanları ters çevrilmiştir. Bu yapıdaki maddeler puanlanırken, 5 ağırlık değerinde olanlar 1'e, 1 ağırlık değerindekiler ise 5'e dönüştürülmüştür. İçsel dinî motivasyon ölçeğinden alınabilecek en düşük puan 10, en yüksek puan ise 50'dir (Karaca, 2001).

İçsel Dinî Motivasyon Ölçeği’nin İngilizce metni, aralarında doktorasını yurt dışında yapmış psikoloji alanında uzman (5) kişiye verilerek, ölçeği Türkçe’ye çevirmeleri istenmiştir. Elde edilen Türkçe çeviri, İngilizce uzmanlarınca tekrar İngilizce'ye çevrilerek, ortaya çıkan İngilizce çeviri orijinal metin ile karşılaştırılarak, değişik çeviriler arasından uzmanların önerileri doğrultusunda her bir maddeyi en iyi ifade ettiği düşünülen çeviriler seçilmiş ve ölçeğin Türkçe versiyonu oluşturulmuştur (Karaca, 2001).

Türkçe'ye çevrilen ve Atatürk Üniversitesi'nde öğrenim gören 194 öğrenciden oluşan örnekleme uygulanan İçsel Dinî Motivasyon Ölçeği’nin güvenirlilik analizlerinde, homojenlik endeks ve yarıya bölme tekniklerinden faydalanılmıştır. Ölçeğin geçerliği ise, yapı geçerlik tekniklerinden faktör analizi ve iç tutarlılık teknikleri kriter alınarak hesaplanmıştır. İçsel Dinî Motivasyon Ölçeği’ni oluşturan maddeler yarıya bölme tekniği ile analiz edildiğinde, iki yarım ölçek arasındaki korelasyon katsayısı .76 olarak hesaplanmıştır (Karaca, 2001).

Turkish Academic Research Review - Türk Akademik Araştırmalar Dergisi https://dergipark.org.tr/tr/pub/tarr 
1110 Eleştirel Düşünme Eğiliminin Dindarlık Üzerine Etkisi: İlahiyat Fakültesi Öğrencileri Örneği

Ayrıca ölçeğin içsel tutarlılık ölçütü olan Cronbach’s Alpha katsayısının .84 olduğu tespit edilmiştir. Ölçeğin geçerliliğini saptamak amacıyla yapılan faktör analizi sonucunda biri hariç ölçek maddelerinin tamamının aynı faktörde kümelendiği görülmüştür. Ölçek maddelerinin iç tutarlılığını tespit etmek amacıyla korelasyon katsayıları hesaplanmış ve ölçek maddelerinin tamamının aynı yönde (pozitif) ayrıştıkları saptanmıştır (Karaca, 2001). Çınar'ın (2020) çalışmasında Cronbach’s Alpha katsayısı .82 olarak hesaplanmıştır. Yapılan çalışmada Cronbach’s Alpha katsayısı .74 olarak tespit edilmiştir (Tablo-2).

\subsection{Verilerin Çözümlenmesi}

Elde edilen tüm veriler SPSS 20.0 istatistik paket programında sayısal değerlere dönüştürülmüş ve programın ilgili modülleri kullanılarak analiz edilmiştir. Araştırmada hangi testlerin kullanılacağına karar verebilmek amacıyla parametrik testlerin temel varsayımlarını karşılama durumları incelenmiştir. $\mathrm{Bu}$ doğrultuda verilerin normal dağılım için çarpıklık ve basıklık dağılımları kontrol edilmiştir. Dağılıma ilişkin veriler Tablo-3'te sunulmuştur.

\section{Tablo 3: Ölçeklere ilişkin değerler}

\begin{tabular}{lllll}
\hline Ölçekler & Skewness & Kurtosis & $\begin{array}{l}\text { Cronbach's } \\
\text { Alfa }\end{array}$ & $\overline{\mathbf{X}}$ \\
& & & & \\
\hline İçsel dinî motivasyon & $-1,026$ & 1,679 & .74 & 4.43 \\
\hline $\begin{array}{l}\text { Eleştirel düşünme } \\
\text { eğilimi }\end{array}$ &,- 408 &, 265 & .95 & 4.01 \\
\hline Üstbiliş & & & & \\
\hline Esneklik &,- 292 &,- 076 & .83 & 4.05 \\
\hline Sistematiklik &,- 501 &, 609 & .85 & 4.07 \\
\hline Azim ve sabır &,- 395 &, 118 & .89 & 3.97 \\
\hline Açık fikirlilik &,- 606 &, 096 & .85 & 3.95 \\
\hline
\end{tabular}

Tablo-3 incelendiğinde örneklemin içsel dinî motivasyon ortalamasının $(\overline{\mathrm{X}}=4.43)$ çok yüksek, eleştirel düşünme eğilimi ortalamasının $(\bar{X}=4.01)$ yüksek olduğu görülmektedir. 
Ölçeklerin normal dağılım şartını sağlaması için çarpıklık ve basıklık değerlerinin +2 ile -2 arasında bir değer almış olması gereklidir (Trochim ve Donnelly, 2006; Field, 2009). Tabloya bakıldığında ölçekler normal dağılım göstermektedir. Yapılan tek değişkenli normallik analizleri sonucunda parametrik testlerin yapılmasının uygun olduğu düşülmüştür.

Analizin ilk aşamasında eldeki veri setinde bağımsız değişkenlerden iki gruplu olanlar için ilişkisiz örneklemler $T$ Testi, üç veya daha fazla gruplu bağımsız değişkenlerde ise One Way ANOVA testi yapılmıştır. Değişkenler arasında anlamlı farklılıkların belirlendiği durumlarda ise farklılaşmaların hangi gruplar arasında olduğunu belirlemek amacıyla varyansların homojen dağıldığı durumlarda çoklu karşılaştırma testlerinden Tukey HSD, varyansların homojen dağılmadığı durumlarda Tamhane's T2 post hoc analizi gerçekleştirilmiştir.

Analizin ikinci aşamasında eleştirel düşünme eğilimleri ile dindarlık seviyeleri arasındaki pozitif ve/veya negatif yöndeki ilişkiyi saptamak amacıyla Pearson Moment Korelasyon analizi gerçekleştirilmiştir. Değişkenler arasındaki ilişkinin derecesini belirlemek amacıyla çoklu doğrusal regresyon analizinden yararlanılmıştır.

Yapılan analiz çalışmalarında anlamlı ilişki tespit edilemeyen durumlar raporlandırılmamıştır. Bu kapsamda, içsel dinî motivasyon ortalama puanlarının sınıf, yaşanılan ortam, algılanan aile yapısı ve aile dindarlık düzeylerine göre anlamlı şekilde farklılaşmadığı görüldüğünden bu durumlar raporlandırılmamıştır. Eleştirel düşünme eğilimi ortalama puanları ise sınıf değişkenine göre anlamlı şekilde farklılaşmadığından raporlandırılmamıştır.

\section{Bulgular}

\subsection{Eleștirel Düşünme Eğiliminin Sosyo-demografik Özelliklere göre Farklılaşmasına Yönelik Bulgular}

İlahiyat Fakültesi öğrencilerinde eleştirel düşünme eğilimi ile sosyo-demografik değişkenler arasında anlamlı farklılaşma olup olmadığına ilişkin One Way ANOVA analizi yapılmış, farklılaşmaların hangi gruplar arasında olduğunu belirlemek amacıyla varyansların homojen dağıldığı durumlarda Tukey HSD, varyansların homojen dağılmadığ 1 durumlarda Tamhane's T2 post hoc analizi gerçekleştirilmiştir. Cinsiyet değişkeni ile eleştirel düşünme eğilimi alt boyutları ve içsel dinî motivasyon arasındaki farklılaşmayı ortaya koymak amacıyla bağımsız değişkenler $\mathrm{t}$ testi analizi yapılmıştır.

Turkish Academic Research Review - Türk Akademik Araştırmalar Dergisi https://dergipark.org.tr/tr/pub/tarr 
1112 Eleştirel Düşünme Eğiliminin Dindarlık Üzerine Etkisi: İlahiyat Fakültesi Öğrencileri Örneği

Tablo 2: Cinsiyet ile bağımlı değişkenler arasındaki farklılıklar

\begin{tabular}{|c|c|c|c|c|c|c|c|}
\hline & Cinsiyet & $\mathrm{n}$ & $\overline{\mathrm{X}}$ & SS & $\mathrm{sd}$ & $\mathrm{t}$ & $\mathrm{p}$ \\
\hline \multirow{3}{*}{ Üstbiliş̧ } & $\mathrm{K}_{1 \mathrm{z}}$ & 236 & 4.06 & .46 & \multirow{3}{*}{294} & \multirow{3}{*}{.911} & \multirow{3}{*}{.363} \\
\hline & & & & & & & \\
\hline & Erkek & 60 & 4.00 & .49 & & & \\
\hline \multirow{3}{*}{ Esneklik } & $\mathrm{K}_{1 \mathrm{z}}$ & 236 & 4.08 & .47 & \multirow{3}{*}{294} & \multirow{3}{*}{.579} & \multirow{3}{*}{.563} \\
\hline & & & & & & & \\
\hline & Erkek & 60 & 4.04 & .55 & & & \\
\hline \multirow{3}{*}{ Sistematiklik } & $\mathrm{K}_{1 \mathrm{Z}}$ & 236 & 3.96 & .54 & \multirow{3}{*}{294} & \multirow{3}{*}{-.134} & \multirow{3}{*}{.893} \\
\hline & & & & & & & \\
\hline & Erkek & 60 & 3.98 & .65 & & & \\
\hline \multirow{2}{*}{$\begin{array}{l}\text { Azim } \\
\text { sabir }\end{array}$} & $\mathrm{K} 1 \mathrm{Z}$ & 236 & 3.96 & .64 & \multirow{2}{*}{294} & \multirow{2}{*}{.769} & \multirow{2}{*}{.443} \\
\hline & Erkek & 60 & 3.89 & .66 & & & \\
\hline \multirow{2}{*}{$\begin{array}{l}\text { Açık } \\
\text { fikirlilik }\end{array}$} & $\mathrm{K}_{1 \mathrm{z}}$ & 236 & 3.92 & .64 & \multirow{2}{*}{294} & \multirow{2}{*}{$\begin{array}{l}- \\
1.431\end{array}$} & \multirow{2}{*}{.165} \\
\hline & Erkek & 60 & 4.05 & .61 & & & \\
\hline \multirow{2}{*}{$\begin{array}{l}\text { İçsel Dini } \\
\text { Motivasyon }\end{array}$} & $\mathrm{K}_{1 \mathrm{z}}$ & 236 & 4.436 & .40 & \multirow{2}{*}{294} & \multirow{2}{*}{.080} & \multirow{2}{*}{.936} \\
\hline & Erkek & 60 & 4.431 & .57 & & & \\
\hline
\end{tabular}

Tablo-4 incelendiğinde İlahiyat Fakültesi öğrencileri örnekleminde eleştirel düşünme eğilimi alt boyutlarında cinsiyete göre anlamlı farklılaşmanın olmadığı görülmektedir (p>.05). Bu bulgularla, Coşkun (2013), Özdemir (2005), Güven ve Kürüm (2007), Şenlik, Baykan ve Aycan (2011), Çekin (2013), Kuvaç ve Koç (2014), Yıldırım ve Şensoy (2017)'un yaptığı araştırma sonuçları uyuşmaktadır. Ancak Zayif (2008) yaptığı çalışmada kadınlar lehine bir fark tespit etmiştir. Buna benzer bir sonuç da Can ve Kaymakçı'nın (2015) çalışmasında dikkatleri çekmektedir. Bu çalışmaya göre kadınlar erkeklere göre meraklılık ve analitiklik alt boyutlarında daha ileri düzeydedir. Yapılan başka bir çalışmada ise kadınların erkeklere göre kendine güven alt boyutu dışında diğer tüm alt boyutlarda daha yüksek düzeyde eleştirel düşünce eğilimine sahip oldukları anlaşılmaktadır (Ocak, Eymir ve Ocak, 2016). Duran (2020) da kadınların erkeklere göre eleştirel düşünme 
eğilim düzeylerinin daha yüksek olduğunu ifade etmektedir. Özdemir, Buyruk ve Güngör (2018) ise erkeklerin kadınlara göre daha yüksek düzeyde eleştirel düşünme eğilimine sahip olduklarını ifade etmektedir. Yapılan araştırma sonuçlarına göre eleştirel düşünme ve cinsiyet değişkeni arasındaki ilişkinin oldukça çeşitli olduğu görülmektedir. Bu çeşitliliğ̈in araştırmaların örnekleminden ve kullanılan ölçeklerin farklı olmasından kaynaklandığı düşünülmektedir. Araştırmada anlamlı farklılaşma olmamasına rağmen ortalamalar incelendiğinde kadınların üstbiliş, esneklik, azim ve sabır alt boyutlarında daha yüksek; erkeklerin ise sistematiklik ve açık fikirlilik alt boyutlarında daha yüksek puanlara ulaştığı tespit edilmiştir.

Tablo-4 incelendiğinde İlahiyat Fakültesi öğrencileri örnekleminde içsel dinî motivasyonda cinsiyete göre anlamlı farklılaşmanın olmadığı görülmektedir ( $\mathrm{p}>.05)$. $\mathrm{Bu}$ bulgu kadınların daha dindar olduğunu ortaya koyan pek çok çalışma ile örtüşmemektedir. Ancak Türkiye'de dindarlık-cinsiyet ilişsisini ortaya konan çalışmaların çoğunda kadınların daha dindar olduğu tespit edilmiştir (Ok ve Cirhinlioğlu, 2011). Duran (2020) yaptığı çalışmada kadınların erkeklere göre dindarlık puanlarının daha yüksek olduğunu ortaya koymuştur. Koç (2010) ise erkeklerin içgüdümlü dindarlık puanlarının kadınlardan daha yüksek olduğunu bulgulamıştır. Bu çalışmada anlamlı farklılı̆̆ın sebebi örneklemin tamamının İlahiyat Fakültesi öğrencilerinden oluşması olarak görülebilir. Nitekim İlahiyat Fakültesi öğrencileri üzerine yapılan çeşitli çalışmalarda da dindarlık boyutunda kadın ve erkek öğrenciler arasında anlamlı farklılıklar bulunmamıştır (Bodur ve Korkmaz, 2017; Karslı, 2019). Araştırmada anlamlı farklılaşma olmamasına rağmen kadınların aldıkları puanların erkeklere göre daha yüksek olduğu tespit edilmiş̧ir.

Tablo 3: Yaşanılan ortam ile eleştirel düşünme eğilimi alt boyutları arasındaki farkl1lıklar

\begin{tabular}{|c|c|c|c|c|c|c|c|c|c|}
\hline & & $\begin{array}{l}\text { Yaşanılan } \\
\text { Ortam }\end{array}$ & $\mathrm{n}$ & $\overline{\mathrm{X}}$ & ss & $\mathrm{sd}$ & $\mathrm{F}$ & $\mathrm{p}$ & $\begin{array}{l}\text { Anlaml } \\
1 \text { Fark }\end{array}$ \\
\hline \multirow{3}{*}{ Üstbiliş } & $\mathrm{A}$ & Köy & 84 & $\begin{array}{l}3.9 \\
8\end{array}$ & $\begin{array}{l}.4 \\
9\end{array}$ & \multirow{3}{*}{$3 / 292$} & \multirow{3}{*}{4.994} & \multirow{3}{*}{$.002 *$} & \multirow{3}{*}{$\begin{array}{l}\text { D-A } \\
\text { D-B }\end{array}$} \\
\hline & B & İlçe & 63 & $\begin{array}{l}3.9 \\
4\end{array}$ & $\begin{array}{l}.4 \\
5\end{array}$ & & & & \\
\hline & $\mathrm{C}$ & Şehir & 49 & $\begin{array}{l}4.0 \\
4\end{array}$ & $\begin{array}{l}.4 \\
7\end{array}$ & & & & \\
\hline
\end{tabular}

Turkish Academic Research Review - Türk Akademik Araştırmalar Dergisi https://dergipark.org.tr/tr/pub/tarr 
1114 Eleştirel Düşünme Eğiliminin Dindarlık Üzerine Etkisi: İlahiyat Fakültesi Öğrencileri Örneği

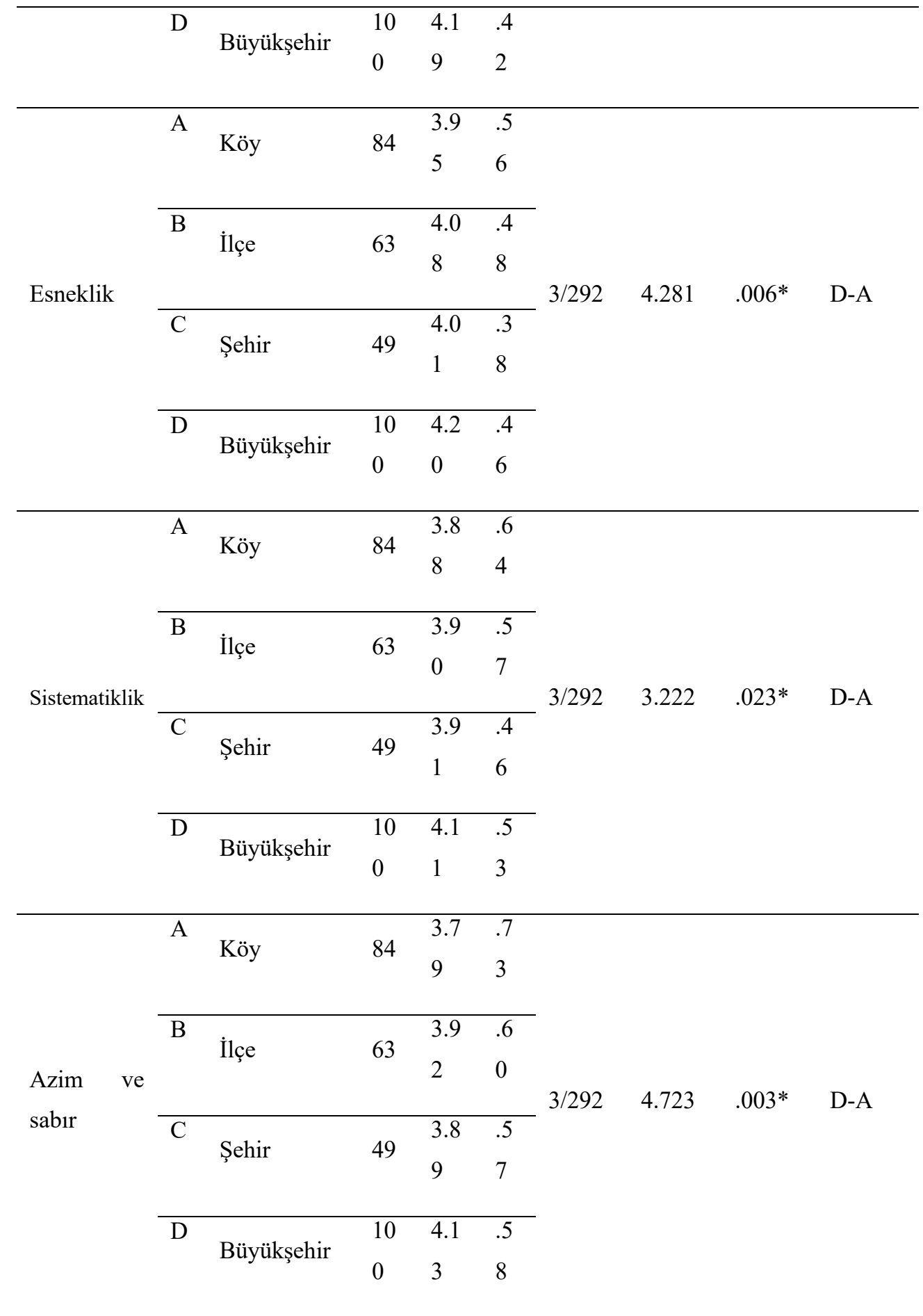

Eleştirel düşünme eğilimi alt boyutlarının yaşanılan ortama göre farklılaşıp farklılaşmadığını ortaya koymak amacıyla yapılan analizde açık fikirlilik alt boyutunda anlamlı farkın olmadığı belirlenmiştir $\left(\mathrm{F}_{3 / 292}=1.595, \mathrm{p}>.05\right)$. Diğer alt boyutlarda ise anlamlı farklılaşmanın olduğu belirlenmiş olup anlamlı farklılıklar 
Tablo-5’te gösterilmiştir. Buna göre büyükşehirde yaşayanların köyde yaşayanlara göre üstbiliş, esneklik, sistematiklik, azim ve sabır alt boyutlarında ortalama puanlarının daha yüksek olduğu belirlenmiştir. Ayrıca büyükşehirde yaşayanların üstbiliş alt boyutunda ilçede yaşayanlara göre ortalama puanlarının daha yüksek olduğu tespit edilmiştir $(\mathrm{p}<.05)$. Araştırma bulgularını destekleyen benzer sonuçlara ulaşılan çalışmalar bulunmaktadır. Özdemir (2005), Coşku (2013), Çekin (2013) ve Duran (2020), çalışmalarında büyük yerleşim yerlerinde yaşayanların eleştirel düşünme puanlarının daha yüksek olduğunu ortaya koymuştur. Bu çalışmaların yanı sıra ilçede yaşayanların il ve köyde yaşayanlardan daha yüksek eleştirel düşünme eğilimine sahip olduklarını ortaya koyan bir çalışma da bulunmaktadır (Polat ve Kontaş, 2018). Akbulut (2019) ise yaşanılan ortam ile eleştirel düşünme eğilimi arasında anlamlı bir farklılık bulamamıştır. Çalışmalardaki bulgu farklılığının temel sebebi olarak örneklem farklılığı görülebilir. İlçede yaşayan insanların daha yüksek eleştirel düşünme eğilimine sahip olduğunu ortaya koyan çalışmada örneklemin yarısını ilçede yaşayan insanlar oluşturmaktadır (Polat ve Kontaş, 2018). Yapılan araştırmaların geneline bakıldı̆̆ında ise şehirde yaşamanın daha çok insanla tanışma, çeşitli sosyal aktiviteler gerçekleştirme vb. imkanlar sunarak eleştirel düşünme eğilimini olumlu yönde etkileyebileceği söylenebilir.

Tablo 4: Sosyo-ekonomik düzey ile eleştirel düşünme eğilimi alt boyutları arasındaki farklılıklar

\begin{tabular}{|c|c|c|c|c|c|c|c|c|c|}
\hline & & $\begin{array}{l}\text { Sosyo- } \\
\text { ekonomik } \\
\text { düzey }\end{array}$ & $\mathrm{n}$ & $\bar{X}$ & ss & $\mathrm{sd}$ & $\mathrm{F}$ & $\mathrm{p}$ & $\begin{array}{l}\text { Anlamlı } \\
\text { Fark }\end{array}$ \\
\hline \multirow{5}{*}{ Üstbiliş } & $\mathrm{A}$ & Düşük & 17 & 3.99 & .69 & \multirow{5}{*}{$4 / 291$} & \multirow{5}{*}{3.101} & \multirow{5}{*}{$.016^{*}$} & \multirow{5}{*}{ - } \\
\hline & B & $\begin{array}{l}\text { Ortanın } \\
\text { alt1 }\end{array}$ & 23 & 3.81 & .49 & & & & \\
\hline & $\mathrm{C}$ & Orta & 183 & 4.04 & .43 & & & & \\
\hline & $\mathrm{D}$ & $\begin{array}{l}\text { Ortanın } \\
\text { üstü }\end{array}$ & 69 & 4.14 & .45 & & & & \\
\hline & $\mathrm{E}$ & Yüksek & 4 & 4.46 & .51 & & & & \\
\hline
\end{tabular}

Turkish Academic Research Review - Türk Akademik Araştırmalar Dergisi https://dergipark.org.tr/tr/pub/tarr 
1116 Eleştirel Düşünme Eğiliminin Dindarlık Üzerine Etkisi: İlahiyat Fakültesi Öğrencileri Örneği

\begin{tabular}{|c|c|c|c|c|c|c|c|c|c|}
\hline \multirow{5}{*}{ Esneklik } & $\mathrm{A}$ & Düşük & 17 & 3.87 & .65 & \multirow{5}{*}{$4 / 291$} & \multirow{5}{*}{2.900} & \multirow{5}{*}{$.022 *$} & \multirow{5}{*}{ - } \\
\hline & $\mathrm{B}$ & $\begin{array}{l}\text { Ortanın } \\
\text { alt1 }\end{array}$ & 23 & 3.87 & .63 & & & & \\
\hline & $\mathrm{C}$ & Orta & 183 & 4.07 & .47 & & & & \\
\hline & $\mathrm{D}$ & $\begin{array}{l}\text { Ortanın } \\
\text { üstü }\end{array}$ & 69 & 4.17 & .42 & & & & \\
\hline & $E$ & Yüksek & 4 & 4.45 & .46 & & & & \\
\hline \multirow{5}{*}{ Sistematiklik } & $\mathrm{A}$ & Düşük & 17 & 3.87 & .75 & \multirow{5}{*}{$4 / 291$} & \multirow{5}{*}{3.149} & \multirow{5}{*}{$.015^{*}$} & \multirow{5}{*}{ D-B } \\
\hline & B & $\begin{array}{l}\text { Ortanın } \\
\text { altı }\end{array}$ & 23 & 3.67 & .72 & & & & \\
\hline & $\mathrm{C}$ & Orta & 183 & 3.96 & .54 & & & & \\
\hline & $\mathrm{D}$ & $\begin{array}{l}\text { Ortanın } \\
\text { üstü }\end{array}$ & 69 & 4.09 & .48 & & & & \\
\hline & $E$ & Yüksek & 4 & 4.38 & .63 & & & & \\
\hline \multirow{6}{*}{$\begin{array}{l}\text { Azim } \\
\text { sabir }\end{array}$} & $\mathrm{A}$ & Düşük & 17 & 3.73 & .81 & \multirow{5}{*}{$4 / 291$} & \multirow{5}{*}{2.841} & \multirow{5}{*}{$.025 *$} & \multirow{5}{*}{ - } \\
\hline & B & $\begin{array}{l}\text { Ortanın } \\
\text { altı }\end{array}$ & 23 & 3.59 & .82 & & & & \\
\hline & $\mathrm{C}$ & Orta & 183 & 3.98 & .60 & & & & \\
\hline & $\mathrm{D}$ & $\begin{array}{l}\text { Ortanın } \\
\text { üstü }\end{array}$ & 69 & 4.02 & .62 & & & & \\
\hline & $\mathrm{E}$ & Yüksek & 4 & 4.18 & .21 & & & & \\
\hline & $\mathrm{A}$ & Düşük & 17 & 4.07 & .67 & \multirow{4}{*}{$4 / 291$} & \multirow{4}{*}{4.158} & \multirow{4}{*}{.003} & \multirow{4}{*}{-} \\
\hline \multirow{3}{*}{$\begin{array}{l}\text { İçsel dinî } \\
\text { motivasyon }\end{array}$} & $\mathrm{B}$ & $\begin{array}{l}\text { Ortanın } \\
\text { altı }\end{array}$ & 23 & 4.29 & .55 & & & & \\
\hline & $\mathrm{C}$ & Orta & 183 & 4.46 & .41 & & & & \\
\hline & $\mathrm{D}$ & $\begin{array}{l}\text { Ortanın } \\
\text { üstü }\end{array}$ & 69 & 4.48 & .37 & & & & \\
\hline
\end{tabular}




$\begin{array}{lllll}\mathrm{E} & \text { Yüksek } & 4 & 4.65 & .31\end{array}$

Örneklemin sosyo-ekonomik düzeylerine göre eleştirel düşünme eğilimi alt boyutlarının farklılaşmasını ortaya koymak amacıyla yapılan analiz çalışmasında açık fikirlilik alt boyutunda herhangi bir anlamlı farklılaşma tespit edilememiştir ( $>$.05). Üstbiliş, esneklik ile azim ve sabır alt boyutlarında yapılan One Way ANOVA analizinde anlamlı farklılık belirlenmesine rağmen farkların hangi gruplarda olduğunun anlaşılması için yapılan post hoc testlerinde herhangi anlamlı bir farklılık tespit edilememiştir. Tablo-6 incelendiğinde sistematiklik alt boyutunda $\left(\mathrm{F}_{4 / 291}=3.149, \mathrm{p}<.05\right)$ sosyo-ekonomik düzeye göre anlamlı farklılaşma olduğu görülmektedir. Buna göre sosyo-ekonomik düzeyi ortanın üstü olanların sistematiklik alt boyutundan aldıkları puanların ortanın altı olanlara göre yüksek olduğu tespit edilmiştir. Yapılan çalışmalarda sosyo-ekonomik düzey ile eleştirel düşünme eğilimi arasında anlamlı farklılaşma bulunamamıştır ancak araştırmalarda sosyo-ekonomik düzeyini yüksek olarak algılayan bireylerin eleştirel düşünme eğilimlerinin diğer gruplara göre daha yüksek olduğu ortaya konulmuştur (Kürüm, 2002; Özdemir, 2005; Dil ve Öz, 2005; Tümkaya ve Aybek, 2008; Erdoğan, 2015; Çekin, 2013; Yıldırım ve Şensoy, 2017).

Tablo 5: Aile yapısı ile eleştirel düşünme eğilimi alt boyutları arasındaki farklılıklar

\begin{tabular}{|c|c|c|c|c|c|c|c|c|c|}
\hline & & $\begin{array}{l}\text { Algilanan } \\
\text { aile yapıs1 }\end{array}$ & $\mathrm{n}$ & $\bar{X}$ & Ss & $\mathrm{sd}$ & $\mathrm{F}$ & $\mathrm{p}$ & $\begin{array}{l}\text { Anlamlı } \\
\text { Fark }\end{array}$ \\
\hline \multirow{5}{*}{ Sistematiklik } & $\mathrm{A}$ & Otoriter & 49 & 4.19 & $\begin{array}{l}.4 \\
9\end{array}$ & \multirow{5}{*}{$5 / 290$} & \multirow{5}{*}{2.718} & \multirow{5}{*}{.020} & \multirow{5}{*}{ E-A } \\
\hline & $\mathrm{B}$ & Demokratik & 24 & 4.03 & $\begin{array}{l}.7 \\
0\end{array}$ & & & & \\
\hline & $\mathrm{C}$ & İlgisiz & 13 & 3.72 & $\begin{array}{l}.6 \\
0\end{array}$ & & & & \\
\hline & $\mathrm{D}$ & Aşırı ilgili & 19 & 4.08 & $\begin{array}{l}.5 \\
4\end{array}$ & & & & \\
\hline & $\mathrm{E}$ & Koruyucu & 107 & 3.90 & $\begin{array}{l}.5 \\
8\end{array}$ & & & & \\
\hline
\end{tabular}

Turkish Academic Research Review - Türk Akademik Araştırmalar Dergisi 
1118 Eleştirel Düşünme Eğiliminin Dindarlık Üzerine Etkisi: İlahiyat Fakültesi Öğrencileri Örneği

\begin{tabular}{|c|c|c|c|c|c|c|c|c|c|}
\hline & $\mathrm{F}$ & Hoşgörülü & 84 & 3.91 & $\begin{array}{l}.5 \\
2\end{array}$ & & & & \\
\hline \multirow{6}{*}{$\begin{array}{l}\text { Açık } \\
\text { fikirlilik }\end{array}$} & $\mathrm{A}$ & Otoriter & 49 & 4.20 & $\begin{array}{l}.5 \\
8\end{array}$ & \multirow{6}{*}{$5 / 290$} & \multirow{6}{*}{2.627} & \multirow{6}{*}{.024} & \multirow{6}{*}{ E-A } \\
\hline & $\mathrm{B}$ & Demokratik & 24 & 3.81 & $\begin{array}{l}.6 \\
5\end{array}$ & & & & \\
\hline & $\mathrm{C}$ & İlgisiz & 13 & 3.84 & $\begin{array}{l}.6 \\
7\end{array}$ & & & & \\
\hline & $\mathrm{D}$ & Aşırı ilgili & 19 & 3.75 & $\begin{array}{l}.7 \\
1\end{array}$ & & & & \\
\hline & $\mathrm{E}$ & Koruyucu & 107 & 3.87 & $\begin{array}{l}.7 \\
0\end{array}$ & & & & \\
\hline & $\mathrm{F}$ & Hoşgörülü & 84 & 4.00 & $\begin{array}{l}.5 \\
2\end{array}$ & & & & \\
\hline
\end{tabular}

Yapılan One Way ANOVA analizinde eleştirel düşünme eğilimi alt boyutlarından üstbiliş, esneklik ile azim ve sabır boyutlarında algılanan aile yapısına göre anlamlı farklılaşma tespit edilememiştir ( $\mathrm{p}>$.05). Sistematiklik ve açık fikirlilik alt boyutlarında ise ailelerini otoriter olarak nitelendiren öğrenciler ile ailelerini koruyucu olarak nitelendirenler arasında anlamlı derecede farklılık belirlenmiştir $(\mathrm{p}<.05)$. Buna göre otoriter ailelerin öğrencilerinin sistematiklik ve açık fikirlilik alt boyutlarında aldıkları ortalama puanların koruyucu ailelerin öğrencilerine göre daha yüksek olduğu tespit edilmiştir. Otoriter olarak algılanan aile yapısının temel özelliği olarak disiplin ve düzenden bahsedilebilir. Bu durum sistematiklik alt boyutunu açıklayabilmektedir. Erdoğan (2015) çalışmasında ailesinin ilgisiz olarak algılayan bireylerin eleştirel düşünme eğilimlerinin diğerlerinden daha yüksek olduğunu ortaya koymuştur. Ayrıca bu araştırmada algılanan otoriter ve demokratik aile tipi arasında otoriter ailenin lehine anlamlı bir ilişki bulmuştur. Bu sonuçların aksine ailesini demokratik olarak algılayan bireylerin eleştirel düşünme eğilim düzeylerinin daha yüksek olduğunu ortaya koyan çalışmalar da bulunmaktadır (Tümkaya ve Aybek, 2008; Güncü, 2018).

Tablo 6: Aile dindarlık düzeyi ile eleştirel düşünme eğilimi alt boyutları arasındaki farkl111klar 


\begin{tabular}{|c|c|c|c|c|c|c|c|c|c|}
\hline & & $\begin{array}{l}\text { Aile } \\
\text { dindarlık } \\
\text { düzeyi }\end{array}$ & $\mathrm{n}$ & $\overline{\mathrm{X}}$ & ss & sd & $\mathrm{F}$ & $\mathrm{p}$ & $\begin{array}{l}\text { Anlamlı } \\
\text { Fark }\end{array}$ \\
\hline \multirow{6}{*}{ Üstbiliş } & $\mathrm{A}$ & Düşük & 5 & 4.40 & .60 & \multirow{6}{*}{$4 / 291$} & \multirow{6}{*}{5.742} & \multirow{6}{*}{$.000 *$} & \\
\hline & $\mathrm{B}$ & $\begin{array}{l}\text { Ortanin } \\
\text { altı }\end{array}$ & 7 & 3.54 & .41 & & & & $\mathrm{E}-\mathrm{C}$ \\
\hline & $\mathrm{C}$ & Orta & 85 & 3.97 & .49 & & & & \\
\hline & & & & & & & & & D-B \\
\hline & $\mathrm{D}$ & $\begin{array}{l}\text { Ortanın } \\
\text { üstü }\end{array}$ & 131 & 4.04 & .43 & & & & B-A \\
\hline & $\mathrm{E}$ & Yüksek & 68 & 4.21 & .42 & & & & \\
\hline \multirow{5}{*}{ Esneklik } & A & Düşük & 5 & 4.43 & .49 & \multirow{5}{*}{$4 / 291$} & \multirow{5}{*}{5.635} & \multirow{5}{*}{$.000 *$} & \\
\hline & $\mathrm{B}$ & $\begin{array}{l}\text { Ortanın } \\
\text { altı }\end{array}$ & 7 & 3.58 & .62 & & & & E-C \\
\hline & $\mathrm{C}$ & Orta & 85 & 3.95 & .53 & & & & E-B \\
\hline & $\mathrm{D}$ & $\begin{array}{l}\text { Ortanın } \\
\text { üstü }\end{array}$ & 131 & 4.07 & .46 & & & & B-A \\
\hline & $\mathrm{E}$ & Yüksek & 68 & 4.23 & .43 & & & & \\
\hline \multirow{5}{*}{ Sistematiklik } & $\mathrm{A}$ & Düşük & 5 & 4.55 & .54 & \multirow{5}{*}{$4 / 291$} & \multirow{5}{*}{8.116} & \multirow{5}{*}{$.000 *$} & \multirow[b]{2}{*}{ E-D } \\
\hline & $\mathrm{B}$ & $\begin{array}{l}\text { Ortanın } \\
\text { altı }\end{array}$ & 7 & 3.43 & .62 & & & & \\
\hline & $\mathrm{C}$ & Orta & 85 & 3.80 & .59 & & & & E-B \\
\hline & $\mathrm{D}$ & $\begin{array}{l}\text { Ortanın } \\
\text { üstü }\end{array}$ & 131 & 3.97 & .52 & & & & C-A \\
\hline & $\mathrm{E}$ & Yüksek & 68 & 4.19 & .50 & & & & \\
\hline \multirow{2}{*}{$\begin{array}{l}\text { Azim } \\
\text { sabır }\end{array}$} & $\mathrm{A}$ & Düşük & 5 & 4.20 & .81 & \multirow[b]{2}{*}{$4 / 291$} & \multirow[b]{2}{*}{3.365} & \multirow[b]{2}{*}{$.010 *$} & \multirow[b]{2}{*}{ E-B } \\
\hline & $\mathrm{B}$ & $\begin{array}{l}\text { Ortanın } \\
\text { alt1 }\end{array}$ & 7 & 3.35 & .57 & & & & \\
\hline
\end{tabular}

Turkish Academic Research Review - Türk Akademik Araştırmalar Dergisi 
1120 Eleştirel Düşünme Eğiliminin Dindarlık Üzerine Etkisi: İlahiyat Fakültesi Öğrencileri Örneği

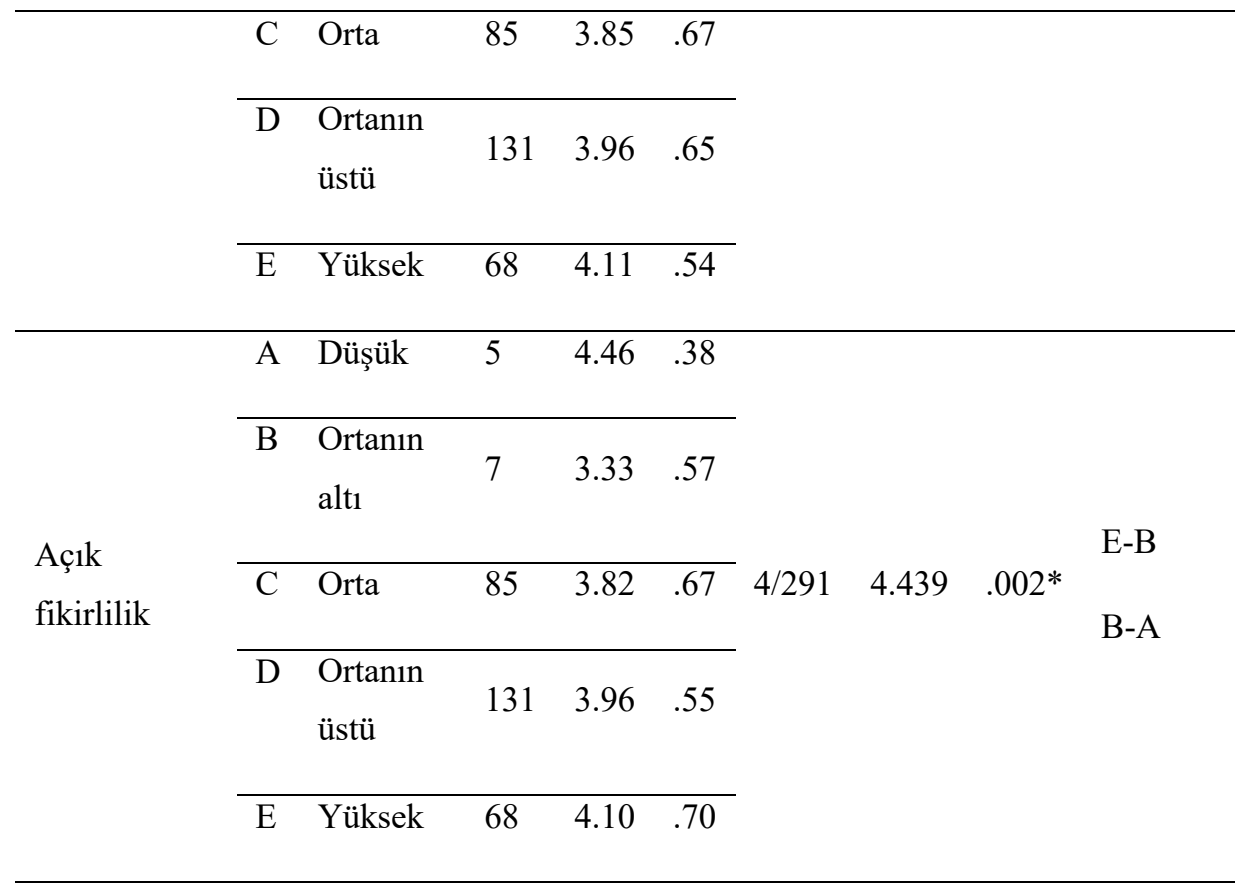

Algılanan aile dindarlık düzeyine göre eleştirel düşünme eğilimi alt boyutlarının anlamlı şekilde farklılaştı̆ı Tablo-8'de görülmektedir. Elde edilen bulgulara göre üstbiliş boyutunda ailesinin dindarlık düzeyi yüksek olanların orta ve ortanın altında olanlara göre ortalama puanlarının daha yüksek, ortanın üstü olanların ortanın altı olanlara göre ortalama puanlarının daha yüksek, düşük olanların ortanın altı olanlara göre puanlarının daha yüksek olduğu belirlenmiştir.

Esneklik boyutunda ailesinin dindarlık düzeyi yüksek olanların ortanın üstü ve orta olanlara göre ortalama puanlarının daha yüksek, düşük olanların ortanın altı olanlara göre puanlarının daha yüksek olduğu belirlenmiştir.

Sistematiklik alt boyutunda ailesinin dindarlık düzeyi yüksek olanların orta, ortanın üstü ve ortanın altında olanlara göre ortalama puanlarının daha yüksek, düşük olanların orta ve ortanın altı olanlara göre ortalama puanlarının daha yüksek olduğu belirlenmiştir.

Azim ve sabır boyutunda ailesinin dindarlık düzeyi yüksek olanların ortanın altı olanlara göre ortalama puanlarının daha yüksek olduğu belirlenmiştir.

Açık fikirlilik boyutunda ise dindarlık düzeyi yüksek olanların ortanın altı olanlara göre ortalama puanlarının daha yüksek, düşük olanların ortanın altı olanlara göre ortalama puanlarının daha yüksek olduğu belirlenmiştir. 
Duran (2020), algılanan aile dindarlık düzeyi ile eleştirel düşünme eğilimi arasında anlamlı bir ilişki bulunmadığını ancak tek yönlü varyans analiz sonuçlarına göre algılanan aile dindarlık durumu değişkeninin alt gruplarının eleştirel düşünme eğilimi puanlarının istatiksel açıdan anlamlı farklılıklar gösterdiğini ortaya koymuştur. En yüksek eleştirel düşünce eğilim puanına algılanan aile dindarlık düzeyi olanlar sahipken onları algılanan aile dindarlık düzeyi orta, ortanın altı, yüksek ve ortanın üstünün takip ettiği söylenmektedir.

$\mathrm{Bu}$ çalışmada tüm alt boyutlarda ve Duran (2020)'nn çalışmasında alt gruplar arasındaki ilişkide algılanan aile dindarlık düzeyi orta ya da ortanın altı iken eleştirel düşünme eğilimi düşmektedir. Duran (2020), bu durumu orta düzeyde dindar olan kişilerin dini bildikleri gibi yaşama ve yaşatma yönündeki ısrarcı tutumlarının, din hakkında yaptıkları ve bildikleri her şeyi kesin doğru olarak kabul etmelerinin ve bu durumu çocuklarına yansıtmalarının bir sonucu olarak değerlendirmektedir.

\subsection{Eleştirel Düşünme Eğilimi ile İçsel Dini Motivasyon Arasındaki İlişkiye Yönelik Bulgular}

Tablo 7: Örneklemin eleştirel düşünme eğilimi ile içsel dini motivasyon ilişkisi

\begin{tabular}{|c|c|c|c|c|c|c|}
\hline & & Üstbiliş & Esneklik & Sistematiklik & $\begin{array}{l}\text { Azim } \\
\text { ve sabır }\end{array}$ & $\begin{array}{l}\text { Açık } \\
\text { fikirlilik }\end{array}$ \\
\hline \multirow[t]{2}{*}{ İDM } & $\begin{array}{l}\text { Pearson } \\
\text { Correlation }\end{array}$ & $.167 * *$ & $.202 * *$ & $.196^{* *}$ & $.200 * *$ & .015 \\
\hline & $\mathrm{p}$ & .004 & .000 & .001 & .001 & .798 \\
\hline
\end{tabular}

Korelasyon ilişkisini ortaya koymak amacıyla yapılan analiz sonuçlarına göre üstbiliş, esneklik, sistematiklik, azim ve sabır alt boyutlarıyla içsel dini motivasyon düzeyi arasında pozitif ve anlamlı ilişki tespit edilmiştir. Buna göre örneklemin eleştirel düşünme düzeyi yükseldikçe dindarlık düzeyi de yükselmektedir.

Çoklu regresyon analizinin temel varsayımları olan, yeterli örneklem büyüklüğü, tekillik olmaması, uç değerler ve normal dağılım göstermesi şartları sağlanmıştır. Yine regresyon analizine ilişkin, Tolerance değerinin .10'dan düşük olmaması, VIF değerinin 10'dan düşük olması, Durbin-Watson değerinin 1 ile 3 arasında olması kriterleri sağlanmış olup (Tabachnick ve Fidell, 2007) ilgili değerler regresyon tablosunda işlenmiştir.

Turkish Academic Research Review - Türk Akademik Araştırmalar Dergisi https://dergipark.org.tr/tr/pub/tarr 
1122 Eleştirel Düşünme Eğiliminin Dindarlık Üzerine Etkisi: İlahiyat Fakültesi Öğrencileri Örneği

Tablo 8: Örneklemin eleştirel düşünme eğilimi ile içsel dini motivasyon ilişkisi (çoklu regresyon)

\begin{tabular}{lllllllll}
\hline Değişken & $\mathrm{B}$ & Hata & $\beta$ & $\mathrm{t}$ & $\mathrm{p}$ & Tolerance & $\mathrm{VIF}$ & $\begin{array}{c}\text { Durbin- } \\
\text { Watson }\end{array}$ \\
\hline Sabit & 3.693 & .211 & - & 17.487 & .000 & - & - & - \\
\hline Esneklik & .182 & .051 & .202 & 3.543 & .000 & 1.000 & 1.000 & 1.954 \\
\hline
\end{tabular}

İçsel dini motivasyon yordanan, eleştirel düşünme eğilimi alt boyutları ise yordayıcı olarak regresyon modeline dahil edilerek gerçekleştirilen analiz sonuçlarına göre $\left(\mathrm{R}=.041, \mathrm{R}^{2}=.038, \mathrm{p}<.05\right)$ esneklik alt boyutunun dindarlık üzerinde pozitif yönlü anlamlı bir yordayıcı olduğu ve içsel dini motivasyona ait toplam varyansın yaklaşık \%4’ünü açıkladığı belirlenmiştir.

Duran (2020)'ın çalışmasında bu bulgunun aksi ortaya konmuştur. Dindarlık düzeyi yükseldikçe eleştirel düşünme düzeyinin düştüğünü bulgulayan çalışmada bu durum; dini anlatan bireylerin, dinin algılanış şeklinin, ailelerin dini öğretme yönteminin genelde itaat ve sınırlandırma bağlamında gerçekleştiği ve bu tür ortamlarda eleştirel düşünme eğiliminin yeterince gelişemediği ifade edilerek açıklanmıştır. Ancak bu çalışmada eleştirel düşünce ile içsel dini motivasyon arasında anlamlı ve olumlu ilişki tespit edilmiştir. Bu durumda iki çalışma arsındaki farkın dindarlık ölçümünde kullanılan ölçeklerle ve araştırma evreniyle ilgili olabileceği düşünülmektedir. Çünkü Duran (2020) Dini Hayat Ölçeğini (DHÖ) kullanmışken bu çalışmada İçsel Dini Motivasyon Ölçeği kullanılmıştır. Duran (2020), evreni Necmettin Erbakan Üniversitesinde öğrenim gören öğrenciler olarak belirlemişken bu çalışmanın evreni Atatürk Üniversitesi İlahiyat Fakültesi öğrencileri olarak belirlenmiştir. Bu farklılıkların sonucunda karşımıza çeşitli bulgular çıkmaktadır. İlahiyat Fakültesi öğrencilerinden oluşan örneklemin; alınan eğitim, aile yapısı ve sosyo-ekonomik durum bakımından farklılık ve çeşitlilik düzeyleri Necmettin Erbakan Üniversitesinde öğrenim gören öğrencilerden oluşan örnekleme göre daha azdır. Bu durumun iki araştırmanın farklı bulgularını açıkladığı düşünülmektedir.

\section{Sonuç}

Eleştirel düşünme üzerine son yıllarda ülkemizde birçok çalışma gerçekleştirilmekte olup eleştirel düşünmenin dindarlık üzerine etkilerine ilişkin çalışmalar yapılması önerilmektedir (Erdoğan, 2015). Araştırmada ilahiyat fakültesi öğrencilerinin sosyodemografik değişkenlere göre eleştirel düşünme eğilimi ve içsel dinî motivasyon 
düzeylerindeki farklılaşmalar ile eleştirel düşünme eğiliminin içsel dinî motivasyonu yordama düzeyi araştırılmıştır. Araştırmanın örneklemini Atatürk Üniversitesi İlahiyat Fakültesi'nde öğrenim gören ve basit seçkisiz örnekleme yöntemiyle seçilen 296 öğrenci oluşturmaktadır. Elde edilen sonuçlara göre, örneklemde eleştirel düşünme eğiliminin alt boyutlarından üstbiliş, esneklik, sistematiklik ve azim-sabır boyutlarıyla içsel dinî motivasyon arasında anlamlı derecede ve pozitif yönde ilişki bulunmaktadır. İçsel dini motivasyon ile açık fikirlilik arasında ise anlamlı bir ilişsi bulunmamıştır. Bu korelasyon değerlerine istinaden yapılan regresyon analizinde eleştirel düşünmenin esneklik alt boyutunun içsel dini motivasyon düzeyini pozitif yönde yordadığı ve toplam varyansın yaklaşık \%4'ünü açıkladığı tespit edilmiştir. $\mathrm{Bu}$ sonuçlar eleştirel düşünmede esneklik alt boyutunun içsel dini motivasyonun önemli bir değişkeni olduğunu göstermektedir. Bu kapsamda bireyin eleştirel düşünme düzeyi yükseldikçe dindarlık düzeyi de yükselmektedir.

Örneklemin içsel dinî motivasyon ortalamasının $(\overline{\mathrm{X}}=4.43)$ çok yüksek ve eleştirel düşünme eğilimi ortalamasının ( $\bar{X}=4.01)$ yüksek olduğu belirlenmiştir. İçsel dini motivasyon düzeyinin çok yüksek olmasının örneklemin İlahiyat Fakültesi öğrencilerinden oluşmasına bağlı olduğu değerlendirilebilir. Bununla birlikte çalışmada örneklemin eleştirel düşünme ortalama puanlarının da yüksek çıkması dikkat çekmektedir. Duran (2020) tarafından gerçekleştirilen ve aynı ölçek kullanılan çalışmada İlahiyat Fakültesi öğrencilerinin diğer fakülte (Tıp, Mühendislik ve Mimarlık, Sosyal ve Beşerî Bilimler) öğrencilerine göre eleştirel düşünme düzeylerinin en düşük seviyede olduğu belirlenmiştir. Literatür incelendiğinde, farklı ölçekler kullanılarak lisans öğrencilerine yönelik yapılan çalışmalarda eleştirel düşünme eğiliminin yüksek veya düşük çıktığını gösteren sonuçlar bulunmaktadır. Örneğin; Küçük'ün (2007) çalışmasında aday öğretmenlerin (lisans 4. sınıf) eleştirel düşünme becerilerini yeterli düzeyde kazanamadıkları ve Gülveren'in (2007) çalışmasında eğitim fakültesi öğrencilerinin eleştirel düşünme becerilerinin yeterli olmadığı vurgulanmıştır. Aynı fakültede okumasına rağmen farklı üniversitelerden oluşan örneklemlerde eleştirel düşünme düzeyleri de farklılık gösterebilmektedir. Schafersman (1991), lisans öğrencilerinin eleştirel düşünme becerilerinin düşüklüğünün, eğitim ortamında öğretim stratejileri ve sınıf tekniklerinin kullanılmadan düz anlatım tarzındaki pasif eğitim yöntemlerinin kullanılmasına bağlı olabileceğini ifade etmektedir.

Türk eğitim sisteminde sorumluluklarını bilen, yapıcı, yaratıcı, geniş bir dünya görüşüne sahip, hür ve bilimsel düşünen bireylerin yetiştirilmesi hedeflenmektedir. Yüksek din öğretimi kurumlarında da benzer amaçlara yer verilerek eleştirel

Turkish Academic Research Review - Türk Akademik Araştırmalar Dergisi https://dergipark.org.tr/tr/pub/tarr 
1124 Eleştirel Düşünme Eğiliminin Dindarlık Üzerine Etkisi: İlahiyat Fakültesi Öğrencileri Örneği

düşünebilen, empati-iletişim kurabilen, uzlaşmaya açık bireyler yetişmesi amaçlı programlara sahip olması beklenmektedir (Turan ve Nazıroğlu, 2021). Eleştirel düşünme becerisinin lisans eğitimi düzeyinde kazandırılmasının gerekliliğine vurgu yapan değerlendirmeler de bulunmaktadır. Araştırmada İlahiyat Fakültesi ögrencilerinin eleştirel düşünme düzeylerinin yüksek çıkmasının ve dindarlık düzeyleri arasındaki anlamlı ilişkinin, öğrenim süreçlerinde farklı dinlere, Tanrı anlayışlarına, mezheplere, amelî veya itikadî görüşlere ilişkin bilgilere yer verilmesine ve öğretici ile müfredatın öğrencileri sorgulayarak öğrenmeye yönlendirilmesine bağlı olabileceği değerlendirilebilir. Nitekim Taştan, Kuşat ve Çelik'in (2001) araştırmasında öğrencilerin çoğu ilahiyat eğitiminin bilgi, düşünce ve davranış değişikliğine katkı sağladığını vurgulamış ve eleştirel düşünme, farklılıklara saygı duyma, hoşgörülü olma gibi vasıflar kazandırdı̆̆ı̆na dikkat çekmiştir. Turan ve Nazıroğlu (2021) tarafından gerçekleştirilen çalışmada örneklemi oluşturan ilahiyat fakültesindeki öğrenciler, öteki ve çatışma konularında arkadaşlarında birtakım eksiklikler olduğunu ifade etmelerine rağmen, empati ve uzlaşma hususlarında olumlu gelişme kat ettiklerini belirtmiştir. Çatışma ve uzlaşma zıtlığı, ilahiyat eğitimin öğrencide meydana getirdiği değişimin somut bir örneğini temsil etmektedir. Buna göre öğrencilerin çoğunun ilahiyat eğitimi süresince empati, uzlaşma ve iletişim kurma konularında az ya da çok olumlu anlamda kendini geliştirdiğini ifade etmesi, bu temsili desteklemektedir (Turan ve Nazıroğlu, 2021).

Eleştirel düşünme eğiliminin esneklik boyutu; gerekli olan tüm bilgilere ulaşmaya çalışma, bilgileri karşılaştıırıen ayrıntıya inme, farklı fikirleri dinleme ve anlamaya çalışma, farklı çözüm yolları sunma ve öğrenilenleri farklı alanlara uygulama hususlarını ifade etmektedir. Bu kapsamda esneklik, hem bilgileri toplama aşamasında farklı bilgilere/fikirlere açı olabilme hem de bilgileri uygulama aşamasında farklı çözümleri farklı alanlarda kullanabilme yetisi olarak ifade edilebilir. Bununla birlikte esneklik boyutunun, farklı eleştirel düşünme ölçeklerinde yer alan açık fikirlilik alt boyutuyla benzer anlamları ifade ettiği değerlendirilebilir. Zihinsel esneklik, eleştirel düşünmeyi olumlu yönde etkileyen önemli etmenlerden biri olup önyargı ve belli bir gruba veya fikre bağımlılığın olmamasıdır (Kazancı, 1989). Esneklik, varsayımları değerlendirme ve tutarlı sonuca ulaşmadır (Kaya, 1997). Öğrencilerin farklı dinî bilgi/görüşler ile karşılaşmaları, farklı dini görüşe sahip öğrenci ve öğretim üyeleri ile bir arada bulunabilmesi hatta farklı düşüncedeki öğrencilerle arkadaşlık ve dostluk kurması, bunun hayatlarında sıklıkla karşılaşılan bir durum olması, tecrübe edilen bu gerçekliğin hayatın içinde var olması, eleştirel düşünmenin esneklik alt boyutunun öğrencilerde zaten var olması beklenen içsel 
dini motivasyonun yordayıcısı olmasını açıklayabilir. Yukarıda ifade edilen çalışmalarda da görüldüğü üzere ilahiyat eğitiminin eleştirel düşünme eğiliminin esneklik alt boyutunu geliştirdiği söylenebilir.

$\mathrm{Bu}$ kapsamda çalışmanın sonuçları çerçevesinde araştırmacılara; İlahiyat Fakültesi öğrencilerinin eleştirel düşünme düzeylerinin nedenlerini ele alan, İlahiyat Fakültesi öğretim programları ile eleştirel düşünme arasındaki ilişkileri ele alan ve eleştirel düşünmenin altında yatan teolojik gerekçeleri ortaya çıkaran nitel/nicel araştırmalar üzerinde araştırma yapılması önerilebilir.

\section{Kaynakça}

Açışlı, S. (2015). Öğretmen Adaylarının Öğrenme Stilleri ve Eleştirel Düşünme Eğilimlerinin İncelenmesi. Necatibey Eğitim Fakültesi Elektronik Fen ve Matematik Eğitimi Dergisi, 9(1), 23-48.

Adorno, T. W. (2011). Otoritaryen Kişilik Üstüne. (Doğan Şahiner çev.), Say Yayınları, İstanbul.

Akbulut, H. (2019). Fen bilimleri öğretmen adaylarının eleştirel düşünme eğilimlerinin tespiti ve çeşitti değiş̧kenler açısından incelenmesi (Yayınlanmamış Doktora Tezi, Trabzon Üniversitesi, Trabzon).

Akarsu, B. (1975). Felsefe Terimleri Sözlüğü. Ankara: Türk Dil Kurumu Yayınları.

Aksu Demirtaş, A. (2019). Sosyal Bilgiler Sosyal Bilgiler Öğretmen Adaylarının Eleştirel Düşünme Düzeyleri (Yüksek Lisans Tezi, Kastamonu Üniversitesi, Kastamonu).

Alkoç, N. (2020). Okulöncesi Öğretmen Adaylarının 21. Yüzyll Öğrenen Becerileri ile Eleştirel Düşünme Eğilimleri Arasında İlişkinin İncelenmesi. (Yayınlanmamış Yüksek Lisans Tezi, Kafkas Üniversitesi, Kars).

Allport, G. W. (2016). Birey ve Dini. (Bilal Sambur, çev.). Elis Yayınları, Ankara.

Âşık Ev, H. (2014). Din Kültürü ve Ahlak Bilgisi Öğretmen Adayları ve Eleştirel Düşünme (Celal Bayar Üniversitesi İlahiyat Fakültesi Birinci Sınıf Öğrencileri Örneği). Journal of International Social Research, 7(32), 425456.

Avaroğulları, A. K. ve Şaman, B. (2020). Sosyal Bilgiler Öğretmen Adaylarının Öğrenme Stilleri ile Eleştirel Düşünme Eğilimleri Arasındaki İlişkinin

Turkish Academic Research Review - Türk Akademik Araştırmalar Dergisi https://dergipark.org.tr/tr/pub/tarr 
1126 Eleştirel Düşünme Eğiliminin Dindarlık Üzerine Etkisi: İlahiyat Fakültesi Öğrencileri Örneği

İncelenmesi. Mehmet Akif Ersoy Üniversitesi Eğitim Fakültesi Dergisi, (53), 411-434.

Bilgiz, M. (2012). Kur'an’da Bilgi ve Düşünce Üretimi. Insan ve Toplum Bilimleri Araştırmaları Dergisi, 1(3), 53-86.

Bodur, H., ve Korkmaz, S. (2017). İlahiyat Öğrencilerinde Sosyal Medya Kullanımı ve Dindarlık İlişkisi. Kahramanmaraş Sütçü İmam Üniversitesi İlahiyat Fakültesi Dergisi, (30), 329-351.

Can, Ş. ve Kaymakçı, G. (2015). Öğretmen Adaylarının Eleştirel Düşünme Eğilimleri. Education Sciences, 10(2), 66-83.

Chaffee, J. (1994). Thinking critically. Boston: Houghton Mifflin.

Cirhinlioğlu, F. G. (2014). Din Psikolojisi. Ankara: Nobel Akademik Yayıncılık, 2. Basim.

Coşkun, M. (2013). Din Kültürü ve Ahlak Bilgisi Öğretmen Adaylarının Eleştirel Düşünme Eğilimleri (İlahiyat-Eğitim DKAB Karşılaştırması). Atatürk Üniversitesi Sosyal Bilimler Enstitüsü Dergisi, 17(1), 143-162.

Cüceloğlu, D. (2000). İyi Düşün Doğru Karar Ver. İstanbul: Sistem.

Çekin, A. (2013). Din Kültürü ve Ahlak Bilgisi Öğretmen Adaylarının Eleştirel Düşünme Becerilerinin Bazı Değişkenler Açısından İncelenmesi. Amasya Üniversitesi İlahiyat Fakültesi Dergisi, (1), 25-46.

Çınar, M. (2020). Üniversite Öğrencilerinde Narsisizm ile İçsel Dini Motivasyon Arasındaki İlişki. Türk Din Psikolojisi Dergisi, (2), 135-160.

Demiralp, C. (2017). Üniversite Öğrencilerinin Empatik Ĕ̆ilim ile Narsistik Kişilik Özellikleri ve Eleştirel Düşünme Arasındaki İlişkinin Incelenmesi (Yayınlanmamış Yüksek Lisans Tezi, Atatürk Üniversitesi, Erzurum).

Dewey, J. (1910). How We Think, Boston: D.C. Heath Publications.

Dil S ve Öz F (2005). Hemşirelik Yüksekokulu ve Beslenme ve Diyetetik Bölümü Öğrencilerinin Eleştirel Düşünme Becerilerini Etkileyen Faktörler. Zonguldak Să̆lık Yüksekokulu Sağlık Eğitim Araştırma Dergisi, 1(1):1225 .

Diyanet İşleri Başkanlığı (2007), Kur'an Yolu: Türkçe Meal ve Tefsir (Cilt 3), H. Karaman (Yay. Haz.) Ankara: Diyanet İşleri Başkanlığı Yayınları. 
Doğan, M. (2014). Dindarlık Sabır ve Psikolojik İyi Olma Arasındaki Ilişskiler. (Yayınlanmamış Doktora Tezi, Atatürk Üniversitesi, Erzurum).

Duran, M. E. (2020). Eleştirel Düşünce ve Dindarllk(Yüksek Lisans Tezi, Necmettin Erbakan Üniversitesi, Konya).

Duran, V. (2019). Öğretmen Adaylarının Akıl Yürütme Stilleri, Bilişsel Çarpıtmaları ve Eleştirel Düşünme Eğilimlerinin İncelenmesi Ondokuz Mayıs Üniversitesi Eğitim Fakültesi Örneği (Yayınlanmamış Doktora Tezi, Ondokuz Mayıs Üniversitesi, İzmir).

Düzgün, Ş.A. (2020), Dini Anlamanın Kılavuzu, Ankara: Otto Yayınları.

Eleştiri. (t.y.). Türk Dil Kurumu güncel Türkçe sözlük içinde.

Erdoğan, İ. (2015). Din Kültürü ve Ahlak Bilgisi Öğretmen Adaylarının Eleştirel Düşünme Eğilim Düzeylerinin İncelenmesi. Marife Dini Araştırmalar Dergisi, 15(2), 321-342.

Esen, M. (2011). Kur'an'da Akıl-İman ilişkisi Ankara Üniversitesi Ilahiyat Fakültesi Dergisi, 2(52), 85-96.

Field, A. (2009). Discovering Statistic Using SPSS for Windows. London: SAGE Publications.

Gazali. (1975). İhya-ı Ulumi'd-Din (Cilt 3), Çev. Ahmet Serdaroğlu, İstanbul: Bedir Yayınevi.

Gibson, C. (1995). “Critical Thinking: Implications for Instruction.” RQ, 1(35), 2736.

Gözüyeşil, A. G. (2020). Öğrenci Hemşirelerinin Alglladıkları Stresin Eleştirel Düşünme Eğilimlerine Etkisi. (Yayınlanmamış Yüksek Lisans Tezi, Çukurova Üniversitesi, Adana).

Gülveren, H. (2007). Eğitim Fakültesi Öğrencilerinin Eleştirel Düşünme Becerileri ve Bu Becerileri Etkileyen Eleştirel Düşünme Faktörleri. (Yayınlanmamış Doktora Tezi, Dokuz Eylül Üniversitesi, İzmir).

Güncü, E. (2018). Üniversite Öğrencilerinin Eleştirel Düşünme Eğiliminin SosyoDemografik ve Kişilik Özellikleri ile Birlikte Araştırılmast: Bir Vakıf Üniversitesi Örneği (Yüksek Lisans Tezi, Çağ Üniversitesi, Mersin).

Turkish Academic Research Review - Türk Akademik Araştırmalar Dergisi https://dergipark.org.tr/tr/pub/tarr 
1128 Eleştirel Düşünme Eğiliminin Dindarlık Üzerine Etkisi: İlahiyat Fakültesi Öğrencileri Örneği

Gündoğdu, H. (2009). Eleştirel Düşünme ve Eleştirel Düşünme Öğretimine Dair Bazı Yanılgılar. Celal Bayar Üniversitesi Sosyal Bilimler Dergisi, 7(1), 5774.

Gürses, İ. (2010). Dindarlık ve Kişilik. Emin Yayınları, Bursa.

Güven, A. ve Kürüm, M. (2007). Öğretmen Adaylarının Sahip Oldukları Öğrenme Stilleri ve Eleştirel Düşünme Eğilimleri. Elektronik Sosyal Bilimler Dergisi, 6(21), 60-90.

Hakkoymaz, S. (2017). Eğitim Fakültesi Öğrencilerinin Eleştirel Düşünme Eğilimleri ile Yazma Kaygıları Arasındaki İlişki. Ihlara Eğitim Araştırmaları Dergisi, 2(2), 24-38.

Hökelekli, H. (2013). Din Psikolojisi. Ankara: Türkiye Diyanet Vakfı Yayınları, 10. Basım.

Kandemir, F. (2016). Umut-İyimserlik ve Dindarlık İlişkisi. (Yayınlanmamış Doktora Tezi, Atatürk Üniversitesi, Erzurum).

Karaca, F. (2001). Din psikolojisinde Metot Sorunu ve Bir Dindarlık Ölçeğinin Türk Toplumuna Standardizasyonu. Ekev Akademi Dergisi, 3 (1), 187-201.

Karaca, F. (2016). Dini Gelişim Psikolojisi, Trabzon: Eser Ofset Matbaacılık.

Karaca, F. (2017). Din Psikolojisi. Trabzon: Eser Ofset Matbaacılık, İlaveli 3. Basım.

Karacoşkun, M. D. (ed.). (2019). Din Psikolojisi El Kitabı. Ankara: Grafiker Yayınları, 5. Basım.

Karayiğit, N. (2017). Mükemmeliyetçilik ve Dindarlık İlişkisi Üzerine Bir Araştırma. (Yayınlanmamış Yüksek Lisans Tezi, Atatürk Üniversitesi, Erzurum).

Karslı, N. (2019). Psikolojik İyi Oluş ve Dindarlık İlişkisi: Trabzon İlahiyat Örneği. Recep Tayyip Erdoğan Üniversitesi Ilahiyat Fakültesi Dergisi, (15), 173-205.

Kaya, M. (1998). Din Eğitimde İletişim ve Dini Tutum. Samsun, Etüt Yayınları.

Kayıklık, H. (2018). Din Psikolojisi Bireysel Dindarlık Üzerine. Adana: Karahan Kitabevi, 5. Basım. 
Kazanc1, O. (1989). Eğitimde Eleştirici Düşünme ve Öğretimi. Ankara, Kazanc1 Hukuk Yayınları.

Kızılgeçit, M. (2011). Yalnızlık Umutsuzluk ve Dindarlı Illişkisi (Yayınlanmamış Doktora Tezi, Atatürk Üniversitesi, Erzurum).

Kızılgeçit, M. (2017). Din Psikolojisinin 100'ü, Ankara: Otto Yayınları.

Kızılgeçit, M. (2020). Din Psikolojisinin 300'ü. Ankara: Otto Yayınları, 1. Basım.

Kiriş Avaroğulları, A. ve Şaman, B. (2020). Sosyal Bilgiler Öğretmen Adaylarının Öğrenme Stilleri ile Eleştirel Düşünme Eğilimleri Arasındaki İlişkinin İncelenmesi. Mehmet Akif Ersoy Üniversitesi Eğitim Fakültesi Dergisi, (53), 411-434.

Koç, M. (2010). Demografik Özellikler ile Dindarlık Arasındaki İlişki Yetişkinler Üzerine Ampirik Bir Araştırma. Uludağ Üniversitesi Illahiyat Fakültesi Dergisi, 19(2), 217-248.

Korlaelçi, M. (1987). Mâturîdî'nin Düşünmeyle İlgili Bazı Ayetleri Te'vili, Erciyes Üniversitesi Sosyal Bilimler Enstitüsü Dergisi, 1, 139-147.

Kökdemir, D. (2012). Üniversite Eğitimi ve Eleştirel Düşünme. PiVOLKA, 21(7), 16-19.

Köse, A. ve Ayten, A. (2015) Din Psikolojisi. İstanbul: Timaş Yayınları, 5. Basım.

Krejcie, R. V. ve Morgan, D. W. (1970). Determining sample size for research activities. Educational and Psychological Measurement, (30), 607-610.

Kuvaç, M., ve Koc, I. (2014). Fen Bilgisi Öğretmen Adaylarının Eleştirel Düşünme Eğilimleri: İstanbul Üniversitesi Örneği.Turkish Journal of Education, 3(2), 46-59.

Küçük, G. (2007). Aday Öğretmenlerin Eleştirel Düşünme Eğilimleri ile Duygusal Zeka Düzeyleri Arasındaki İlişki (Yayınlanmamış Yüksek Lisans Tezi, Abant İzzet Baysal Üniversitesi, Bolu).

Kürüm, D. (2002). Öğretmen Adaylarinın Eleştirel Düşünme Gücü (Yüksek Lisans Tezi, Anadolu Üniversitesi, Eskişehir). Erişim Adresi: https://tez.yok.gov.tr/UlusalTezMerkezi/tezSorguSonucYeni.jsp

Meadow, M. J. ve Kahoe, R. D. (1984). Psychology of Religion. Newyork: Harper and Row.

Turkish Academic Research Review - Türk Akademik Araştırmalar Dergisi https://dergipark.org.tr/tr/pub/tarr 
1130 Eleştirel Düşünme Eğiliminin Dindarlık Üzerine Etkisi: İlahiyat Fakültesi Öğrencileri Örneği

Mckee, J. S. (1988). Impediments to Implementing Critical Thinking. Social Education, 52: 444-446.

Ocak, G., Eğmir, E. ve Ocak, İ. (2016). Öğretmen Adaylarının Eleştirel Düşünme Eğilimlerinin Çeşitli Değişkenler Açısından İncelenmesi. Erzincan Üniversitesi Eğitim Fakültesi Dergisi, 18(1), 63-91.

Özdemir, S. M. (2005). Üniversite Öğrencilerinin Eleştirel Düşünme Becerilerinin Çeşitli Değişkenler Açısından Değerlendirilmesi. Türk Eğitim Bilimleri Dergisi, 3(3), 297-316.

Paul, R. ve Elder, L. (2008). Minik Eleştirel Düşünme Kılavuzu: Kavramlar ve Araçlar (Merih Bektaş Fidan çev.).

Peterson, M., William H., Reichenbach B. ve Basinger D. (2013). Akıl ve İnanç: Din Felsefesine Giriş, çev. Rahim Acar, İstanbul: Küre Yayınları.

Polat, M. ve Kontaş, H. (2018). Sınıf Öğretmenlerinin Eleştirel Düşünme Eğilimlerinin İncelenmesi. Elektronik Sosyal Bilimler Dergisi, 17(65), 142159.

Ramazan, Y. (2020). Düşünmenin Alfabesi. İstanbul: Babil Kitap.

Schafersman, Steven D. (1991). An Introduction to Critical Thinking, 1-13.

Semerci, N. (2000). Kritik Düşünme Ölçeği. Eğitim ve Bilim, 25 (116), 23-26.

Semerci, N. (2016). Eleştirel Düşünme Eğilimi Ölçeğinin (EDE) Geliştirilmesi: Geçerlik ve Güvenirlik Revize Çalışması. Turkish Studies, 11(9), 725-740.

Söylemez, Y. (2016). İçerik analizi: eleştirel düşünme. Ekev Akademi Dergisi, 20(66), 671-696.

Şahinel, S. (2007). Eleştirel Düşünme. Ankara: Pegem A Yayıncılık.

Şen, S. N. (2016). Okul Öncesi Eğitimi Öğretmen Adaylarının Eleştirel Düşünme Ĕ̌ilimleri, Empati Kurma Becerileri ve Mesleki Kaygı Düzeyleri Arasındaki İlişkinin Incelenmesi (Yayınlanmamış Yüksek Lisans Tezi, Çanakkale Onsekiz Mart Üniversitesi, Çanakkale).

Şenlik, N. Z., Balkan, Ö. ve Aycan, Ş. (2011). Öğretmen Adaylarının Eleştirel Düşünme Becerileri: Muğla Üniversitesi Örneği. Celal Bayar Üniversitesi Fen Bilimleri Dergisi, 7(1), 67-76. 
Şeriati, A. (2019). Dine Karşı Din. Ankara: Fecr Yayınları, 14. Basım.

Tama, M. C. (1989). Critical Thinking: Promoting It in the Classroom. ERIC.

Taştan, A, Kuşat, A ve Çelik, C. (2001). Üniversite Düzeyinde Din Öğretimi Alan Öğrencilerde Eğitim Sürecinde Oluşan Tutum ve Davranış Değişiklikleri (Erciyes Üniversitesi İlahiyat Fakültesi Örneği). Erciyes Üniversitesi Sosyal Bilimler Enstitüsü Dergisi, 1 (11), 169-192.

Topçu, N. (2011). Íslam ve İnsan Mevlana ve Tasavvuf, İstanbul: Dergah Yayınları.

Trochim, W. M. ve Donnelly, J. P. (2006). The Research Methods Knowledge Base. (3. Bask1). Cincinnati OH: Atomic Dog.

Tunçer, E. (2020). Ortaokul Matematik Öğretmenlerinin Eleştirel Düşünme Ĕgilim ve Uygulama Algıları Arasındaki İlişki. (Yayınlanmamış Yüksek Lisans Tezi, Düzce Üniversitesi, Düzce).

Turan, Ş ve Nazıroğlu, B. (2021). Dini Uzlaşma Kültürü Bağlamında İlahiyat Eğitimi. Darulfunun Illahiyat, 32 (1), 219-256.

Tümkaya, S. ve Aybek, B. (2008). Üniversite Öğrencilerinin Eleştirel Düşünme Eğilimlerinin Sosyo-demografik Özellikler Açısından İncelenmesi. Çukurova Üniversitesi Sosyal Bilimler Enstitüsü Dergisi, 17(2), 387-402.

Yapıcı, A. (2007). Ruh Sağlığı ve Din: Psiko-Sosyal Uyum ve Dindarlık. Adana: Karahan.

Yaran, C. S. (1997). Dinî Epistemolojide Eleştirel Akılcılık ve Tahkikî İmancılık. Ondokuz Mayıs Üniversitesi Ilahiyat Fakültesi Dergisi,9(9), 217-238.

Zayif, K. (2008). Öğretmen Adaylarının Eleştirel Düşünme Ĕgilimleri (Yayımlanmamış Yüksek Lisans Tezi, Abant İzzet Baysal Üniversitesi, Bolu).

Turkish Academic Research Review - Türk Akademik Araştırmalar Dergisi https://dergipark.org.tr/tr/pub/tarr 